\title{
Emotional, energetic, and entelic interpretants: epistemic and ethical pragmaticism in Ibri, Peirce, and Aristotle
}

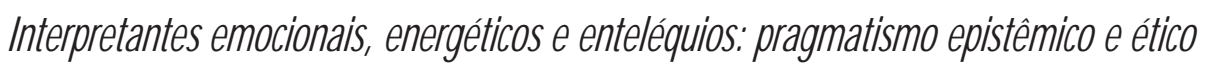 enllai, PeirceeAistáteles}

\author{
David Dilworth \\ Stony Brook University - USA \\ dd9414@aol.com
}

\begin{abstract}
Peirce's ontological semeiosis reprised Aristotle's sense of rational praxis in their shared sense of the mediating function of the Logical Interpretant. The paper proceeds in three parts. The first outlines Ivo Assad Ibri's conceptualization of Peirce's semeiosis in respect to the difference between the Emotional and Logical Interpretant, particularly with regard to the former in the "degenerate" modes of fixing belief and conduct; the second explicates Peirce's initial conceptualization of that doctrine in his treatment of the "Man-sign" in "Some Consequences of Four Incapacities" (1868); a third part features Aristotle's Nicomachean Ethics as classical provenance of the main trajectory of Peirce's semeiosis, by way of correlating Peirce's concept of development teleology with Aristotle's parallel concept of active dispositional character (bexis) energized by the ethical mean (mesotes) as the pragmatistic interpretant of conduct.
\end{abstract}

Keywords: Agapism. Developmental Teleology. Emotional Interpretant. Energetic Interpretant. Hexis. Logical Interpretant. Semeiosis. Tychism.

Resumo: A semiótica ontológica de Peirce retomou o sentido de práxis racional de Aristóteles em seu sentido compartilhado da função de mediação do Interpretante lógico. O artigo está dividido em três partes. A primeira delineia a conceitualização de Ivo Assad Ibri da semiose de Peirce com relação à diferença entre o Interpretante emocional e o lógico, em especial com relação ao primeiro nos modos "degenerados" de fixação de crença e conduta; a segunda parte explica a conceitualização inicial de Peirce daquela doutrina em seu tratamento do "Homem-signo" em "Some Consequences of Four Incapacities" (1968); a terceira parte apresenta a Ética a Nicômaco de Aristóteles como a origem clássica da trajetória principal da semiose de Peirce, ao correlacionar o conceito de teleologia de desenvolvimento de Peirce com o conceito paralelo de caráter disposicional ativo de Aristóteles (hexis) energizado pela média ética (mesotes) como o interpretante pragmatista da conduta.

Palavras-chave: Agapismo. Teleologia de desenvolvimento. Interpretante emocional. Interpretante energético. Hexis. Interpretante lógico. Semeiose. Tiquismo. 
Data de recebimento: 10/10/2019

Data de aceite: $07 / 11 / 2019$

DOI: $10.23925 / 2316-5278.2019 v 20 \mathrm{i} 2 \mathrm{p} 304-342$

\section{Introduction}

This paper takes its point of departure from recent contributions by Ivo Assad Ibri focusing on Peirce's semeiotic doctrine of Emotional and Logical Interpretants. ${ }^{1}$ In tandem with that, my paper's own endeavor will be to explore a reciprocally interpreting relation that presents itself between Peirce's ontological semeiotics and their classical provenance in Aristotle, more specifically in his Nicomachean Ethics.

Peirce's theory of signs developed as an outgrowth and expanded generalization of many sources, including his early-phase reaction to Friedrich von Schiller and Immanuel Kant, to contemporary formulations of Darwinism, to the logics of De Morgan and Boole, as well as incentivized by his mathematical and logical expertise and his interest in the broader history of philosophy that richly dipped back into the medieval scholastics and to Aristotle (EP 1:xxxi). In this regard, I will submit, Aristotle should be accorded pride of place on this list. ${ }^{2}$ A comprehensive account will inform us that Peirce, through his early interest in revising Kant's transcendentalist categories, reprised and amplified a significant range of Aristotle's thought, accomplishing this reprisal in conscious phases of epistemic, ethical, ontological, and semeiotic articulation. ${ }^{3}$

Taking an even longer-range view of the matter, Peirce often averred that his categories were not new, and not his own. One expression of this averral is to be found in an amusing preamble to a lecture Peirce penned in 1903:

I trust, ladies and gentlemen, that I have not conveyed the idea that the three categories about which I have been discoursing are a discovery of mine. If they were, that circumstance would be an almost conclusive proof of the falsity of the list. Ideas so fundamental as I hold them to be must have been uralt when the Neanderthal man was a child. They must be traceable in the minds of the inferior animals. Much more must they have permeated human thought since Pherecydes. No, all that I have done is to give them an exposition of them which, I hope, puts them in a clearer light than Hegel (MS 319:3-4).

If Peirce's mythical Pherecydes replaces Hegel in order of philosophic exposition of his three categories, it becomes less of the stretch for the historian of philosophy's imagination to give Aristotle-as Hegel in fact insisted-the pride of place. Peirce's story of putting a clearer light to Hegel's categories is a significant strain of his

1 See Ibri, 2017a, 2017b (2015), 2018a, 2018b; 2019, p. 177-193.

2 See Everett, 2019.

3 See Dilworth (1989), which interfaces the partially converging and diverging archic profiles of Aristotle and Kant, and thus for Kant's transcendentalist revision of Aristotle's categories in the roll-out of his own "critical" project. 
writings worth the telling. ${ }^{4}$ But, as I recommend in this paper, Peirce's categorical relation to Aristotle's classical provenance should take precedence. At any rate, I will here endeavor to tell the tale of their reciprocal interpretation on certain key functional issues.

In the nature of this complex conceptual interrelation, my present paper can endeavor to provide only one of several smoothly fitting keys to open Peirce's semeiotic relation to Aristotle. My limited approach will be to suggest that Ivo Ibri's way of parsing the categorical difference between Crude/Emotional and Logical Interpretant can be enlisted as a heuristic key into the heart and soul of Aristotle's Nicomachean Ethics; but conversely, Aristotle's great classic_-arguably the greatest (read: truest) work in the history of philosophy_can reciprocally provide significant access to the heart and soul of Peirce's semeiotics.

Now in regard to the correlation between Aristotle's ethical pragmaticism and Peirce's semeiotic pragmaticism, Ibri has made a magisterial contribution to Peirce studies in clarifying how Peirce's later-phase semeiotics ramified into considerations of both negative and positive significations of "universals" centered on the difference between the Emotional and Logical Interpretant, respectively. In fact, this topic began to exercise Peirce before he was thirty. Peirce's articulation of certain implications of the "degenerate" forms of "fixing belief" (and therefore of the "conduct of life") trace back to his Questions Concerning Certain Faculties Claimed for Man (1868) and its companion piece, Some Consequences of Four Incapacities (1868), the latter of which contained Peirce's first explication of his doctrine of the "Man-sign" in proto-semeiotic and arguably neo-Aristotelian terms.

Briefly to forecast this reciprocally illumining parallelism, Aristotle's Nicomachean Ethics synoptically outlined the gamut of the intellectual and moral virtues and vices, and, with regard to the latter, specifically focused on the dimension of practical moral intelligence (praxis) and its experiential outcomes in the form of rational mediation of psychic energies characterized as "feelings and actions" and "pleasures and pains." In so doing he explicitly formulated a doctrine of selfactivating character (bexis)_or, as we will see, "personality" as "developmental teleology" in Peirce's terms-which takes the right measure of feelings, actions, and habits of human conduct in an account of the rational activity of the soul. The Nicomachean Ethics turned on its key prescription of the "mean" (mesotes, intermediate) which functions as a rationally measuring potency-namely, in the case of virtuous conduct-a potency mediating the nutritive, appetitive, and the rational part of the soul's decisional activities in the civilized arenas of Ethics and Politics. ${ }^{5}$ Peirce, in his more generalized epistemological, moral, and ontological semeiosis, arguably reprised Aristotle's sense of rational praxis in his categorically

4 See, for example, Dilworth, 2015.

5 In the Nicomachean Ethics, a soul-ruinous developmental teleology occurs in the case of the "base" person beset with the negative momentum of vices. Though outside the scope of this paper, a corresponding doctrine of the Confucian gentleman vs. the "base" partisan factionalist is conspicuous in the classical Confucian concept of moral teleology in which, arguably, the moral characteristic of "sincerity" plays the role of Aristotle's mesotes and of Peirce's Logical Interpretant. For this inter-textual correlation, see DILWORTH, 1989, p. 65-83. 
Third sense of mediating function of the Logical Interpretant. Peirce reprised that doctrine within his Pragmatism, later revised as Pragmaticism.

Perforce, my approach to this significant interface in the history of philosophy requires a degree of speculative imagination combined with a sufficient effort of textual exegesis. To align certain pragmatic-pragmatistic aspects of Aristotle's Nicomachean Ethics with Peirce's semeiotics of Emotional and Logical Interpretant, I will proceed in three segments of articulation. First, I will outline Ivo Ibri's conceptualization of Peirce's semeiosis of the difference between Emotional and Logical Interpretants, particularly with regard to the sense of Emotional as a Crude Interpretant in the "degenerate" modes of fixing belief; second, an exegesis of Peirce's initial approach to that doctrine in his treatment of the "Man-sign" in Some Consequences of Four Incapacities (1868); third, such an exegesis of Peirce's earlyphase writing will feature Aristotle's Nicomachean Ethics as the classical provenance of Peirce's formulations.

\section{Ivo Ibri's conceptualization of Peirce's semeiotics of crude and logical interpretant}

Let me assume here the gradual evolution of Peirce's Three Categories in his career-text culminating in what Ivo Ibri and other scholars have identified as his non-nominalistic, ontological semeiotics. (I will be employing throughout Peirce's preferred term "semeiotics" that hews closer to the Greek word, sêmeion). The seeds of this trivalent categoriology of signs later blossomed into Peirce's idealism-realism of a "Universe perfused with signs." 6 These seeds can be traced from his Harvard undergraduate writings on Friedrich von Schiller, on through his early endeavor to reformulate Kant's categories (as in On a New List of Categories, 1867) and his already substantial epistemological essays of Questions Concerning Certain Faculties Claimed for Man (1868), Some Consequences of Four Incapacities (1869), The Fixation of Belief (1877), and How to Make Our Ideas Clear (1878); then blossomed, in his middle phase, into cosmological and metaphysical categories beginning with A Guess at the Riddle (1887-88); and thereafter in new levels of articulation in essays on Pragmaticism and related subjects from 1903 on.?

6 "It is a strange thing, when one comes to ponder over it, that a sign should leave its interpreter to supply a part of its meaning, but the explanation of the phenomenon lies in the fact that the entire universe,- - not merely the universe of existents, but all the wider universe, embracing the universe of existents as a part, the universe which we are accustomed to refer to as the 'truth,'- that all this universe is perfused with signs, if not composed exclusively of signs. Let us note this in passing as having a bearing upon the question of pragmaticism." (EP 2:394).

7 Certain commentators have concentrated on Peirce's early epistemological writings to the neglect of the ascendant developmental curve of his career-text. His middlephase metaphysical essays published in the Monist journal between 1891-93-The Architecture of Theories, The Doctrine of Necessity Examined, The Law of Mind, Man's Glassy Essence, and Evolutionary Love-should be recognized as one of the bursts of genius in the history of philosophy. But then, the almost 200 pages of The essential Peirce (EP 2:242-433), provide the ample evidence of further groundbreaking theory in his later career. These include Chapter 17, What Makes a Reasoning Sound (composed in the summer and delivered in November 1903); a large document supplementary to 
My purpose here will not be to rehearse this developmental teleology of Peirce's thought at every point, but rather only to insist that it consisted of a continuous growth in Peirce's career. As well, my limited space here will not allow a fuller narrative setting Peirce's philosophic accomplishments in the historical matrix of his times, especially in the story of his capping, in his original categorical terms, a $19^{\text {th }}$-century trans-Atlantic philosophic paradigm that traces back to Kant and the Jena-zeit transformation of the German Enlightenment associated with the careers of such figures as Goethe, Fichte, Schelling, and Hegel, which in turn were further mediated by the writings of Coleridge, Emerson, and others, on the way to Peirce.

My first positive endeavor will be to outline Ivo Ibri's application of Peirce's Three Categories to the interfacing matters of contemporary informational systems and the pragmatic conduct of life that Peirce put in the particular focus of his conceptualizing four bottom line Methods of Fixing Belief. I will add my historian of philosophy's perspective that Peirce's doctrine was neo-Aristotelian in that it rendered in his own terms the implications of practical wisdom in the moral conduct of life (and its absence) to be found in Aristotle's corpus of philosophic writings. Specifically, Aristotle's Nicomachean Ethics can be seen as framing a pragmatistic analogue of Peirce's more expansively articulated doctrine of inductive and abductive inference along the gamut of energetic-entelic processes of nature and mind. ${ }^{8}$

the Lowell Lectures of 1903, A Syllabus of Certain Topics in Logic which contains Chapter 18, An Outline Classification of the Sciences, Chapter 19, The Ethics of Terminology, and Chapter 20, Sundry Logical Conceptions; then, Chapter 21, Nomenclature and Divisions of Triadic Relations, as Far as They Are Determined, and Chapter 22 New Elements (probably written in early 1904); another essay on speculative rhetoric or semiotics, followed by Chapter 23, Ideas, Stray or Stolen, about Scientific Writing (written in late 1904); and his renaming of Pragmatism as Pragmaticism in the substantial Chapter 24, What Pragmatism is (composed in the middle of 1904). Just after the appearance of the Nation review in 1905 Peirce published Chapter 25, Issues of Pragmaticism (completed in June 1905); Chapter 26, The Basis of Pragmaticism in Phaneroscopy (August through December 1905); followed by Chapter 27, The Basis of Pragmatism in the Normative Sciences (January 1906); and Chapter 28, Pragmatism (composed March-April 1907).

8 Ivo Ibri has astutely caught the full nuance of this in the title of his Kósmos Noetós. In another paper I hope to develop conspicuous parallels of the same concept in East Asian (e.g., Confucian and Neo-Confucian) philosophic sources. In the West, PLATO's laterphase doctrine of the World-Soul in the Timaeus can be cited as one of the philosophic origins of the concept of Kósmos Noetós. It then underwent major transformations (arguably closer to Peirce's "Reason and the Logic of Things") in the writings of ARISTOTLE as well as in the noetic cosmomonism of the STOICS and PLOTINUS. After lying fallow in traditions of dualistically theologized Medieval Philosophy, it emerged again in the revitalized SPINOZISM of the German Romantics, conspicuously in Goethe, Friedrich Schlegel, and Schelling, whose influences in turn trace through to Emerson and Peirce. (Goethe, Schlegel, and Emerson wrote poems on the World-Soul.) For a useful introduction into this latter topic see Miklos Vassanyi: "As far as the early period of German Romanticism is concerned, the ultimate synthesis of the world-soul theory seems to be SCHELLING'S The Ages of the World (Die Weltalter), in which Jewish (LURIA, HERRERA) and Christian (BÖHME, OTTINGER) Cabbalistic, theosophical, Trinitarian, mystical (MEISTER ECKART, BRUNO), and natural philosophical conceptions (of 'Creation' as the result of a divine chemistry) merge to form a speculative, systematically 
Now Ibri indicates how Peirce's categorical approach evades every anthropocentric, ergo dualistic and nominalistic, basis of conceiving the philosophic variables. Habit-formation is cosmical; the universe is self-organizing. It is a Kósmos Noetós as an infinitely deploying symbolical Interpretant. Consistent with Aristotle's front and center doctrine of character formation-(see more below)-Ibri thereby features Peirce, the logical and ontological semiotician par excellence, as expounding the bottom line notion of habit as a rule of conduct formed by generalization, or, in his synthetical inferential terms, by induction (2017b, p. 194). Scientific inquiry, which presupposes "the irritation of doubt" by the "non-dicible" modalities of Firstness (esthetical qualisigns) and Secondness (indexical sinsigns), is a vitally grounded process of Thirdness - that is, of continuously unfolding and self-correcting Logical Interpretants worked out in the epoch-transcending generations of symbol-making communities of intelligent minds. Such forms of Logical Interpretants transcend reduction to "crude" Emotional Interpretants which, in Ibri's clarification, feed the roots of "degenerate" fixations of belief and conduct, namely, the Science-retardant forms of Tenacity, Authority, and Apriorism.

Ibri's analysis astutely illumines Peirce's early classic The Fixation of Belief (1877) to explicate Peirce's core doctrine of habits of belief resulting from inductive generalization. Chronologically, however, it can be noted that Peirce already spelled out initial lineaments of this theory in his Some Consequences of Four Incapacities a decade earlier (in 1868). "Some Consequences," hailed by Peirce himself as one of his most important writings, stands as a dense, earlier foray in the direction of his later semeiotics, consisting of a segment on the "Man-sign," which contained his classification of the three valid forms of inference (deduction, induction, bypothesis), and his formulation of habit as process of inductive generalization in the two forms of probable inference, namely induction and bypothesis.

Of these types of inductive habit-formation (qua Logical Interpretation) characterizing the processes of authentic scientific inquiry-and which I am extending, via Aristotle, to the moral sphere of the conduct of life-Ibri draws on Peirce's later-phase doctrinal variants of what he called Statistical or Quantitative and Qualitative Induction. Statistical Induction proceeds by characterizing a ratio of repetitive marks (CP 7.120-123). Taking into account the reality of randomness or spontaneous chance (Firstness), such inductive ratios are quantitative samplings of signs bestowing degrees of probable assurance in Peirce's fallibilistic theater of inferential inquiry. Scientific inquiry is predicated on constant verification of such quantitative inductions: but-what is more-requires new bypothetical starts whenever the existing statistical paradigm of inductive adherence falls short of comprehending new "data" in the heuristic process of inquiry. It is Qualitative,

expounded though not always convincing theology, of the divine potencies" (2011, p. 387). For his part, Peirce, in the opening paragraph of The Law of Mind (1892), cited- "for the benefit of those who are curious in studying mental biographies" - the influence on his thought by Ralph Waldo Emerson, Frederic Hedge, and their other Transcendentalist friends who were "disseminating the ideas that they had caught from Schelling, and Schelling from Plotinus, from Boehm, or from God knows what minds stricken with the monstrous mysticism of the East" - a legacy that he (Peirce), "after a long incubation," proposed to modify by mathematical conceptions and by training in physical investigations (EP 1:312-313). 
or Hypothetical, Induction that opens up the possibility of further inquiry for Quantitative verification.

Here, then, as Ibri has astutely clarified, Peirce inscribed the heuristically Qualitative Induction as distinguished from the Statistical to account for the so-tospeak progressive upturn in new inquiry. As opposed to the unprogressive modalities of fixed belief, Statistical Inductive is already generative of degrees of fallible probabilities in inquiry and conduct; but throughout his career Peirce's prioritized the re-generative function of Qualitative Induction in the connatural discoveries of nature and mind.

Now, in later phases of his writings, distinct from such possible positive expansions of inquiry (scientific, ethical, and artistic) by Quantitative and Qualitative Induction, Peirce introduced a further nomenclature via the term Crude Induction. Under the general classification of the generic forms of semeiosis by the categorical concepts of Feelings, Energetic Acts, and Habits, he designated Feeling as Emotional Interpretant having either the positive status of a "pure First" kind of qualitative Feeling per se, or having a negative status of commotional Emotional Feeling in association with the categorical energy of Secondness.

Crude/Emotional Interpretant in the latter sense resonates literally and figuratively with crude as "raw, uncooked." It is such "raw, uncooked" or "immature" inductions that motivate the "degenerate" fixations of belief and the conduct of lifeas in Peirce's early-phase classifications of Tenacity, Authority, and Apriorism. That is to say, "Crude" Inductions short-circuit the progressive teleology of inquiry and conduct of life in the positive inferential modalities of both Statistical and Qualitative Induction. It arrests the latter, freezing a "felt mass of phenomena" into a universal and necessary stasis. In certain instantiations it may dogmatize-absolutize-a "felt mass" of Crude Interpretant into an undigestible, non-negotiable "universal" bloc of predicates that forestalls the possibility of any further semeiotic dialogue, that is to say, of any further fallibilistic evidential inquiry of Logical Interpretants. (Conflictual religious animosities, psychological "hang-ups, "deep fake" moral outrage, media "raw meat" in forms of "hysterical hate speech" in the divisive "cancel culture" of our times, are obvious examples of degenerate Crude Induction that traverse the dialogic possibility of objective Logical Interpretation).?

Ibri's bottom line is to highlight Peirce's doctrine of "raw feeling" at the base of Crude Induction, such that it is always representative of irrefutable, closeddown, universal generalization, with its attendant deductive logic controlling the re-

9 In the United States, the still feverish manifestations of the "hate and hysteria" politics of the Trump Derangement Syndrome (TDS) and attendant daily exposures of the "Fake News" of the leftwing Media, are other obvious contemporary political examples; but the list can be expanded indefinitely in historical and contemporary perspectives. The Fixation of Belief by the Method of Authority (Authoritarianism) deserves a separate presentation by itself as illustrating Peirce's concept of Crude Emotionality by the weaponized methods of indoctrination and intimidation. On the home front, Peirce's treatment of this second method of fixing belief (he called it "moral terrorism") fits like a glove the current "political correctness" agenda of the university. And it goes without saying that the great works of literature-cf. Dante and Shakespeare-reveal the three degenerate methods of fixing belief by Tenacity, Authority, and Apriorism as perennially intertwined in history's real-life situations. 
iterations of its various self-imploding parts. ${ }^{10}$ Such internally self-centered assertions that interdict the possibilities of rational outcomes have their classical description in Aristotle's classification of the degenerate excesses and deficiencies of "feelings and actions" that prevent the outcomes of intellectual and moral virtue, as well as in his further classification of even more ruinous kinds of extreme vice that have no opposites in the catalog of virtues (as in the doomed circles of the damned in Dante's Inferno that closely repossessed the architectonic of Aristotle's Ethics). ${ }^{11}$

Back to the Crude or Emotional Interpretant. As Ibri further clarifies, Feelings are comprised, first, of pure qualisigns having the character of "continuities without logical form and in this way constitute genuine possibilities under pure firstness"; as such, in the language of the Three Categories, they can function to "cloud that essential categorical otherness able to create a state of doubt [...] [though they also may function as] the starting point of new inquiry." But in another respect, when appearing as commotional psychological affections they may congeal into "cathected" (Freud), that is, "turbo-charged," emotional determinations, which deconstruct, deflect, detour, the possibilities of intelligent re-presentational processes.

Notoriously, on the excessively extreme side of such self-universalized blockages of the possibilities of dialogic conversation, religious and secular hate rhetoric and the hysterical zombie activism in our so-called contemporary "culture of complaint" manifestly function to undercut free speech. However, Crude Interpretants run the neurotic gamut of civilization and its discontents. ${ }^{12}$

As indicated above, Qualisigns of Firstness that combine with commotional determinations of Secondness are postulated here as "functioning" (Aristotle's ergon, "working") in degenerate form, whereas, in positive modalities of the symmetrically connatural phenomena of nature and mind, they function as the proliferating spontaneities and factical discoveries framed in Peirce's signature doctrine of symbolical semeiosis. Here again, much has also to be positively said of the tychistic nature of "pure appearances" (Friedrich von Schiller) that have their analogue in the "nutritive" manifestations of "refreshing" animation that are also inscribed in

10 Ibri remarks that Peirce's text appears to be absent of an example of Qualitative Induction. Here we might think of Peirce's appreciation of Kepler's abductive inferences concerning the elliptical orbits of the planets as one example of Logical Interpretant-and from there go to Peirce's many historical lessons of the "uberous" ("gravid with new birth") nature of instinctive guessing in scientific inquiry. The reverse story of the forcible confinement of Galileo's putative scientific "free speech rights" by authoritarian and ideological fixations of theological and scientific beliefs, is paradigmatic in its own way.

11 Reference to Dante's architectonic repossession of Aristotle's Ethics in medieval Christianity suggests linking Peirce's ontological semeiotics with the mainstream of Western civilization. In this light see Peirce's own declared aspiration "to make a philosophy like that of Aristotle, that is to say, to outline a theory so comprehensive that, for a long time to come, the entire work of human reason, in philosophy of every school and kind, in mathematics, in psychology, in physical science, in history, in sociology and in whatever other department there may be, shall appear as the filling up of its details." (EP 1:247).

12 As a less dramatic example, we might cite Peirce's critique of John Stuart Mill's austere empiricism of Statistical Induction that is absent the heuristic prospecting of Qualitative Induction, as another species of "closed universal," based on John Stuart Mill's false axiom of the "uniformity of nature." (EP 1:104, 76-77, 177-179, 217). 
Aristotle's De Anima and Nicomachean Ethics, respectively.

Ibri renders this positive side in addressing the phenomenology of Qualisigns and Sinsigns. He astutely thematizes "pure experiences under the two categories that do not involve objective time, namely, Firstness and Secondness." Pure experience of Firstness is "consummated in the form of free contemplation of the qualities of an object, be it natural or not [as in a beautiful landscape or work of art] endowed with internal continuity." Ibri cites Peirce's profession that in the light of his categories the "esthetic good" must be construed as the "mood of simply contemplating the embodiment of the quality" - a kind of per se self-enjoying Samadhi of the Buddha in the Zen literature. Precedent to William James' later formulation in his Essays on Radical Empiricism, Peirce's "pure experience" of Firstness is prior to the subjectobject duality of consciousness, as he already spelled out programmatically in $A$ Guess at the Riddle (EP 1:248). In other passages Peirce expresses the need of a contemplative "Musement" to achieve such a capacity for the appreciation of pure qualisigns; but as well, such imaginative experiences of the sublime "admirability" of the universe at large become fresh incentives for moral conduct (EP 2:434-440).

Now Ibri astutely construes this phenomenological semeiosis of contemplative Firstness of "pure experience" in an apt reference to Schopenhauer's doctrine of the temporary "denial of the will" in the pure transparency of aesthetic contemplation. Schopenhauer's doctrine in The World as Will and Representation traces back to Kant's third Critique's theory of the power of reflective judgment-that is to say, of the a priori judgments of the beautiful and the sublime and the spirited animations of genius in the fine arts, which transcend Kant's a priori domains of both cognitive and desiring faculties. ${ }^{13}$

Neither aesthetical qualisigns nor physical sinsigns link them to objective time, which Ibri calls Chronos. Objective time is chrono-logical time that is rather involved in the symbolical plane of legisigns (Thirdness). But Qualisigns constitute the proto-primal ingredients in Peirce's tychistic cosmology, thus again subtending the abductory trajectories of heuristic inquiry in general as well as the phenomenological and normative classifications of esthetic consummation. Peirce's "richest heuristic hypothesis"-Ibri avers-consists in the implications for the synthetical judgment as a "mixture of quality and legisign," or the logical form and continuous unity of feeling in the hypothetical process of creative discovery and invention.

Here Ibri admirably frames the theory of connatural habit-formation in nature and art. One can think of the influence of Goethe, Schiller, Schelling, and Emerson: matter is "effete," "partially deadened" mind until brought up to its higher potency by, in Peirce's word, "the divination of genius." Connatural human genius is continuous with and a higher level "outlet" (that is, entelic "outcome") for the pentup unconscious mental strivings of Nature. Nature continues to come into being through the plastic acts of creative human cognition bringing nature's evolutionary

13 Peirce's own explicit theory of heuristic progress of inquiry tout court announced in A Guess at the Riddle, and his (for the most part implicit) phenomenology of aesthetic contemplation-further mediated by Schiller, Schelling, and Emerson-is arguably traceable to the same locus classical in Kant's third Critique. Peirce, however, diverges from both Kant and Schopenhauer when he doubts the possibility of hierarchizing grades of esthetic qualities (see IBRI, 2017b, p. 199; and Peirce, CP 5.133 and MS 310). 
strivings to conscious expression. ("Strivings" as in Goethe's key words Streben and Metamorphosis.) That the human imagination is part of the world's unfolding metamorphoses of its intrinsic truth overturns the Cartesian-Newtonian-Kantian dichotomies of mind and world, as well as the cross-the-board materialisms and nominalisms of the modern and post-modern eras.

As Ibri avers, this phenomenology of kairotic and chrono-logical discovery "inspired the cosmogenesis of Peirce's categories." The legisigns of Nature spring from Nature's own habit-tendencies toward symbolical generalization. This is also one of the central implications of Peirce's One Law of Mind (CP 7.515; EP 1:312 ff). The one-off indicative sinsign of actual objective determination functions as the linking categorical sign between the generality of the qualisign and the generality of the legisign. Peirce's theory of categorical trivalence grounds the role of the mind's metamorphosis from the modal "maybe" of possibility of the qualisign to the modal "would be necessity" of the legisign. The three compresent categories render this trivalent process of input-throughput-output. It is the open-ended generality of the incorporating Thirdness of the symbolical legisign that implicates the outcomes of a cosmogenetic semeiosis that-once again-goes beyond the arresting universality of Crude Induction as well as the presumptive uniformity of nature in the austere empiricist's model of Statistical Induction sans Qualitative Induction. ${ }^{14}$

\section{Peirce's initial adumbration of the doctrine of emotional and logical interpretants in Some Consequences of Four Incapacities}

As noted above, Peirce, in his later-phase, articulated what amounts to two different versions of Emotional Interpretant. In one context he developed his semeiotic classification of "Three Kinds of Induction," which he calls Crude, Quantitative, and Qualitative (CP 2:757, and 2.759, 1905; see also CP 6:473, 1908). In another context, ${ }^{15}$ in the terms of a more comprehensive classification of Three Kinds of Interpretants, Peirce speaks of Emotional, Energetic, and Logical Interpretants. Each of these classifications ring changes on his overall categorical trichotomy of Feeling, Act, and Habit (MS 318:253, 419-421, and passim).

In the terms of this latter, and broader, classification, "Feelings" are "pure

14 Quantitative or Statistical Induction "assigns a definite value to a quantity. It draws a sample of a class, finds a numerical expression for a predesignate character of that sample and extends this evaluation under proper qualification to the entire class, by the aid of the doctrine of chances" (CP 7:120, 1903). A contemporary version of the Statistical Induction can be thought to obtain in the exponential proliferation of technically driven "quantitative data" in AI algorithmic models of Quantitative Induction. As indicated above, Peirce's tychistic doctrine of spontaneities of nature traversed J. S. Mill's version of Statistical Induction on the point of the latter's axiomatic presumption of an absolute uniformity of nature.

15 MS 318:63-69, 251, 281-89. Cf. Felicia E. Kruse (1990, p. 216-217; and 1997, p. 138140). I am indebted for these references from the pre-published draft of Nicholas Guardiano (2019) which traces the worldview of semiotic consciousness in New England Transcendentalism, with particular focus on the background of Peirce's doctrine of the poetical Emotional Interpretant featured in the prose and poetry of his "Concord neighbor," Ralph Waldo Emerson. 
affects" (cf. Friedrich von Schiller's "pure appearances") of Firstness with their internal continuities functioning as Rhematical Qualisigns per se:-e.g., the beauty of a landscape "speaks for itself," as does Beethoven's "Apassionata" sonata. In the terms of the alternative classification, Feelings may function "crudely" as degenerate Thirds, psychologized feelings as predominately Seconds, consisting of reductively universalized, subjectively preoccupied, "affections."

Qualitative Induction, by contrast to either Crude or even to Statistical Induction, has a very Aristotelian ring to it: it functions as a "mean" or intermediate potency of "concrete reasonableness" in the reason-able streams of life experiences. In one of Peirce's many articulations:

The remaining kind of induction, which I call Qualitative Induction, is of more general utility than either of the others, while it is intermediate between them, alike in respect to security and to scientific value of its conclusions. It consists of those inductions which are neither founded upon experience in one mass, as Crude Induction is, nor upon a collection of numerable instances of equal evidential values [as in Statistical Induction], but upon a stream of experiences in which the relative evidential values of different parts of it have to be estimated according to our sense of the impressions they make on us. (CP 2.759, 1905, emphasis added; apud IBRI, 2017).

Crude Inductions, which are "founded upon experience in one mass," have the logical value of cast-iron propositions, blocking the road of prospective inquiry and conduct, as distinction from the "more general utility" of Qualitative Inductions. ${ }^{16}$ Crude Inductions suck up all the semeiotic oxygen in the room, having a logical force of apodictic deductions from hide-bound universal premises. Quantitative Inductions are familiar to us in "polling data" as well as in the probability propositions of intra-paradigm scientific practices. But the chief value of Quantitative Induction is to suggest new heuristic outcomes of Qualitative Induction; the latter, in its turn, re-generates the possibilities of new inductive processes.

Given Peirce's synechistic Law of Mind, both "aptitudes" of Feeling (Qualitative and Crude) have deep roots in the habit-formations of personal temperament as well as in communal traditions of cultural histories. Aristotle captured the essential mark of this in his concept of hexis, the acquired "second nature" of selfactivating dispositions of character. No less than a historical community, a person's developmental character is a "would be" culture, a tradition, a manifest destiny.

Now, as we have seen, Ibri astutely parses three of the four kinds of Methods of Fixing Belief as falling under the classifications of Emotional Interpretant in the Crude sense, as distinction from the dialogic form of genuine, inter-generational, scientific practice. Authentic inquiry is fallible but self-corrective, based on progressive

16 "The first and weakest kind of inductive reasoning is that which goes on the presumption that future experience as to the matter at hand will not be utterly at variance with all past experience" (CP 2.276, 1905). "I call this Crude Induction. It is the only one which concludes a logically Universal Proposition" (CP 6.473, 1908). Both citations appearing in Ibri, 2018. 
realizations of true and false (which Aristotle carried over to the real distinction between morally good and $b a d$ ). Ibri is also keen to emphasize the positive side of Peirce's doctrine with regard to the "kairos" possibilities of the rhematical qualisign of pure aesthetical Feeling; but in this context, his focus is on the "degenerate" forms of fixing belief (Tenacity, Authority, Apriorism) by Crude Interpretants. Peirce's later writings re-framed the same doctrine within his architectonic classification of the Normative Sciences under the third branch of Semeiotics, more specifically in the sub-classification of Critic which defines the generic kinds of the valid and invalid inquiry.

Now the seminal traces of these different parsings of Emotional Interpretant already appear in Peirce's early-phase writings on the logic of science. (His intellectual biographer should account for the remarkable fact that the young Peirce began to focus on the semeiosis of Emotional Interpretant in his pre-30-year-old writings!) He did so even before he was invited to lecture on the British logicians by way of co-participating in a sequence of 1870-1871 Harvard's proto-Philosophy Department courses together with Ralph Waldo Emerson, Frederic Hedge, and several other prominent figures of that day. ${ }^{17}$ In Some Consequences of Four Incapacities (1868), in respect to the third of the four consequences of certain incapacities claimed for cognition, Peirce wrote, in positive form, of the Man-sign's authentic capacity to think in synthetical inferences, and in that context inscribed a substantial prelude to his later-phase doctrines of Emotional (in the two senses, primal and retarding) and Logical Interpretants. And he adumbrated this focus in his preceding essay of 1868, Questions Concerning Faculties Claimed for Man, when he wrote: "On the other hand, there are certain other feelings - the emotions, for example-which appear to arise in the first place, not as predicates at all, and to be referable to the [subjective] mind alone." (EP 1:23).

Peirce's agenda in the sequent essay, Some Consequences of Four Incapacities, was to adjudicate, from the logician's perspective, false assumptions of the epistemological tradition running from the "intuitionist" claims of Cartesian rationalism to the "sensationalist" premises of the classical British empiricists with regard to certain incapacities of the inquiring mind. He rejected these premises by exposing a first epistemic incapacity, the presupposition that an introspective selfknowledge of subjective mind can be obtained "[...] which is not inferred from any character of outward things." And then by critiquing a second incapacity, namely "[W]e have no power of Intuition, but every cognition is determined logically by previous cognitions"- which extended the first incapacity while adding a sense of the ongoing momentum of the stream of outward or inner experience. Giving the example of a man who is angry, he averred:

In the same way any emotion is a predication concerning some object, and the chief differences between this and an objective intellectual judgment is that while the latter is relative to human nature or to mind in general, the former is relative to the particular circumstances and disposition of a particular man

17 The immediate fruit of this focus was Peirce's early pronouncement for Scotistic realism in his review of Fraser's The Works of George Berkeley (EP 1:81 ff). 
at a particular time." He continued: "What is here said of the emotions in general, is true in particular of the sense of beauty and of the moral sense; good and bad are feelings which first arise as predicates, and therefore are either predicates of the not-I, or are determined by previous cognitions (there being no intuitive power of distinguishing subjective elements of consciousness). (EP 1:23, emphasis added).

Peirce's agenda here, insightful with respect to the sense of beauty and the moral sense, was to establish the logical form of inquiry in general such that intelligible predication, for its part, is clarified to consist in sign-transference in the combined objective and subjective semeiotic processes of lived experience. Here he adumbrated his rejection of fixing belief by the emotional method of subjective tenacity in insisting: "But thus to make single individuals absolute judges of truth is most pernicious." (EP 1:29). Also preluding Peirce's mid-career expression of his objective idealism or ideal-realism-and here consistent with his elaboration of the third incapacity that "We have no power to think without signs"-Peirce further averred: "Every un-idealistic philosophy presupposes some absolutely inexplicable, unanalyzable ultimate, in short, something from mediation itself not susceptible to mediation" (EP 1:29-30). And further probing the logical status of the ongoing processes of sign-transference, he remarked that "Something, therefore, takes place in the organism which is equivalent to the syllogistic process." And this led him to an articulation of the three forms of syllogistic inference, namely of "complete" (as in deduction, which is apodictic, unconditional) and "incomplete," namely, of two "probable" types of inference, induction and bypothesis. (EP 1:30-33). In sequent passages he refers to these as three species, but one genus, of valid inference (EP $1: 35,37)$.

Now in this context the young Peirce can also be seen concerned with parsing the difference between Statistical (or Indicative), also called Quantitative Induction- "a syllogism in which all the members of a class or aggregate have all the characters which are common to all the members of the same class"-and Hypothesis (Abduction or Qualitative Induction)_ "a syllogism or argument that proceeds from the assumption that a character which is known necessarily to involve a certain number of others may be probably predicated of any object which has all the known characters of the others." The latter "substitutes for a great series of predicates forming no unity in themselves a single one (or small number) which involves them all." And therefore "Hypothetical reasoning may be called reasoning from consequent to antecedent" (EP 1:35). ${ }^{18}$

Further, in this context of discussing the "Man-sign" Peirce ostensibly laid the basis of his three semeiotical categories. "Man thinks"-he averred- "in conscious signs, in some feeling, image, conception, or other representation. [...] Everything that is present to us (and our existence is proved by ignorance and error) is a phenomenal manifestation of ourselves [...]. This does not prevent it from being a manifestation of something without us, just as a rainbow is at once a manifestation

18 A n argument from analogy, Peirce further clarified, combines induction and hypothesis, and is then analyzable into a deduction or an induction, or a deduction and a hypothesis. 
of both the sun and the rain." When we think, therefore, we at that moment "appear as a sign" - and a sign has three references_- "a sign to some thought that interprets it, of some object to which that thought is equivalent; and in some respect or quality which brings it into connection with its object" (EP 1:38).

Building on this trivalent explication of sign-aspects, Peirce honed in on the "Trains of thought" that follow "the laws of associations" wherein and whereby "events occupy [...] time, and come to pass by a continuous process." The "thought process" names a suppositum, i.e., the outward thing, but linked in the sequence of previous thoughts of the same object (EP1: 39). In addition to this Third aspect of the interpretive process in the association of ideas, he repeated this elaboration of the trivalence of sign-transference in the words: "The two other properties of a sign (which is not identical with the thing signified) are its material quality, or some respect or character it has in itself and has nothing to do with its representative function, and its connection with another sign of the same object, or with the object itself (e.g. usefulness of some signs such as weathercocks, tallies, pictures), which consist in their real physical connection or power of association with the brainsign-which is to say, "[...] the pure demonstrative [indexical] application of the sign." (EP 1:40).

Therefore, in this early-phase version of his trivalent semeiosis, "The representative function of the sign" lies neither in the material quality [Firstness] or in a real relation to its object [Secondness], but which it is to a thought [Thirdness], a conception which is a meaning, a logical comprehension, involving as mental events, acts of the mind, in a continuous sequence of re-presentations of thoughts that are independent in time"-which is why the association of resembling thoughts in the sequence has a hypothetical character-whereas "no thought in itself, i.e., no feeling in itself, contains any others, but is absolutely simple and unanalyzable,"ergo, qua immediately present, is incomparable, and sui generis. Therefore, "every thought in so far as it is a feeling of a peculiar sort is simple, an ultimate, inexplicable fact." Because the feeling per se is evanescent to its possible reflection and we can never bring it back as it was in and for itself, such present feelings "contain only what is universal," having no intellectual value, are not reflectively knowable in the sequence of representation, and "so the meaning of a thought is altogether something virtual." (EP 1:42, emphasis added).

It follows that such feelings containing only what is universal and having no representational value "fall into the contradiction of making the Mediate immediable." It is true that such an Immediate, the Unanalyzable, the Unintellectual, runs in a continuous stream through our lives- "it is the sum total of consciousness"-but it is also true that "mediation, which is the continuity of it, is brought about by a real [re-presentative] force behind [immediate] consciousness." Hence, again, we have "the three elements" in genuine thought, namely, the representative function, the denotative application, and the material quality or how it feels. (EP 1:42).

In this context Peirce goes on to observe that a sensation is not necessarily an immediate intuition, or first impression of sense; this is evident in the "sense of beauty" which-as he has previously discussed in the case of a pitch of a tone in sound-depends "[...] not on the contemplation of a mere feeling but on the rapidity with which certain impressions are successively conveyed to the mind" (EP 1:15). The sensation of beauty is determined by previous cognitions, thus always arising as 
a predicate of something we think beautiful. (So too with our sense of color.) The sensation of a beautiful something arises on a manifold of comparisons with other impressions. The sensation of beauty is then a simplifying predicate taken in place of a complex manifold of predicates; "in other words, it fulfills the function of a hypothesis" (EP 1:42; cf. EP 1:23 above). Therefore, a sensation resembles the class of hypothetic inferences in the form of reasoning from definition to a definitum in which the major premise is of an arbitrary nature. A sensation thus gets caught up in the conventions of language and by the constitution of our nature by which natural signs arise - thus determined by logical laws, by previous cognitions. But as a mere feeling of a particular sort, it is not a representation, only determined as an inexplicable, occult power, only the material quality of a mental sign.

Now, this dense discussion led Peirce to consider the logical status of Emotional Interpretants. "Feelings" enter into the representational process as predicates of something determined logically by the feelings which precede it; feelings not subsumed in the normal development of predicative intelligence would be the "emotions." Such emotions are so-to-speak energetic but not entelic, consisting in the commotional form of efficient causality (Secondness). Whenever a man feels, he is thinking of something, some object of thought, suffused with a degree of subjective passion. That is why, he says, "we look on emotions more as affections of self than other cognitions" - and we find them "more dependent on our accidental constitution at the moment" and thus "recognize them as cognitions too narrow to be rationally useful."

Or again, in Peirce's words: "The emotions [...] arise when our attention is strongly drawn to complex and inconceivable circumstances." Here he gives such examples as fear, joy, disappointment, and anxieties, "which replace our capacities of intellectual hypothetic references to the future" (EP 1:43). He followed this with further examples of emotive experiences such as wonder, hope, angry incomprehensionwhereas a scientific explanation has the opposite, a cooling effect. Though these kinds of commotional emotions can begin to energize entelic predicates, they may, and often do not; rather, they may an arrest a further simplification of predicates, thereby becoming a kind of detouring, or deferral, at least for the emotionally excited moment, of the possibility of further hypothetic inferences. "Now if we consider that a very complex predicate demands explanation by means of an hypothesis, and that the hypothesis must be a simpler predicate substituted for that complex one, then when we have an emotion, an bypothesis, strictly speaking, is bardly possible" (EP 1:44). ${ }^{19}$ The complexity of commotional feeling-often "over-charged" or "cathected" in Freud's sense-short-circuits the electric flow of predication that could be released by ongoing hypothetical intelligence.

Although concerned here primarily with the deferral of hypothetical intelligence by what he later termed the Emotional Interpretant, we see here as well, in nuce, an earlier version of Peirce's classic essay on the "hide-bound" negative fixations of belief and their prospective release in scientific inquiry. Throughout his career, Peirce featured hypothetical (abductive) inference as the front-edge of uberous inquiry and of the agapic conduct of life in general. Here, precedent to the doctrine of "The Fixation of Belief" of 1877, he continued to probe the non-dicible, pre-

Cf. Aristotle: "No one can think during sexual intercourse." 
intelligent, characteristics of emotional fixations. As noted above, such energies are "crude" in the literal sense of being "raw and uncooked." Crude in French derives from cru, signifying "growth," as in the viticultural phrase grand cru. But a "vintage" grand cru harvest has to go through a long process of fermentation and then further years of chemical maturation in the barrels. "Crudités" in French are the plates of appetizers such as morsels of uncooked carrots, celery, broccoli, cherry tomatoes, etc., served at a party or a picnic. They do not add up to a full meal. You cannot live a healthy life on them.

Emotions may provide food for intelligent thought—as they do for creative people of all stripes-but just as well can dam up in their commotional whirlpool. Peirce adumbrated his later nomenclature of Crude Emotionality when he went on to say:

Compared to a sensation [first impression of sense qua material ground], which is not a thought and which does not have a large influence on the current of thought, an emotion, on the other hand, comes later in the development of thought-I mean, further from the first beginning of the cognition of its object-and the thoughts which determine it already have motions corresponding to them in the brain, or the chief ganglion; consequently, it produces large movements in the body, and independently of its representative value, strongly affects the current of thought. The animal motions to which I allude, are, in the first place and obviously, blushing, blenching, staring, smiling, scowling, pouting, laughing, weeping, sobbing, wriggling, flinching, trembling, being petrified, sighing, sniffing, shrugging, groaning, heartsinking, trepidation, swelling of the heart, etc., etc. To these may, perhaps, be added, in the second place, other more complicated actions, which nevertheless spring from a direct impulse and not from deliberation. (EP 1:44-45, emphasis added).

It is impossible to exhaust Peirce's list ${ }^{20}$ We might note in passing that Peirce here reprised Hobbes's psychology of the "vital" and "animal motions." Aristotle's Ethics already has another provenance in its elaborate list of moral and immoral predicates of "pleasure and pains," the latter energized by "appetitive-affective" excesses and defects of "character." (Dante then repossessed the entire gamut of Aristotelian moral and immoral predicates in his Divine Comedy.) My previous reference to the

20 Peirce's ensuing writings are replete with further illustrations of the list. In the The Fixation of Belief (1877) he developed the point that "most of us [...] are naturally more sanguine and hopeful that logic would justify" (EP 1:112). In the same essay he referred to the kind of self-denial involved in remaining complaisant in a former belief, rather than expose oneself to the irritation of doubt: "[...] the pleasure he derives from his calm faith overbalances any inconvenience resulting from its destructive character" (EP 1:116). Then the entire section on the second Method of Fixing Belief (Authority) is replete with the language of "ruthless power" and the effects of "moral terrorism" on the "intellectual slaves" of populations whose "passions" are enlisted to regard unorthodox opinions with "hatred and horror" or "be terrified into silence" (EP 1:117). 
many ranges of psychological illness and immaturity- "toxic habits," and all other kinds of "cathected" conduct of life in the varieties of self and communal "hangups" and "discontents" - will verify Peirce's articulation of the emotional fixations of belief and conduct.

Thus, as I will argue in the sequel, the young Peirce, in this early-phase epistemological consideration of emotionality, even while set within his primary concern for the logic of scientific inquiry, repossessed the gist of classical theories of epistemic and ethical pragmatism, and, most like-mindedly, the framing of the moral virtues (and vices) outlined in Aristotle's Nicomachean Ethics. ${ }^{21}$

But back here to Peirce's Some Consequences of Four Incapacities of 1868. With regard to the consideration of the "Man-sign," he went on to say: "That which distinguishes both sensation proper [Firstness] and emotions [Secondness] from the feeling of a thought [Thirdness], is that in the case of the two former the material quality is made predominant, because the material ground [as well as the commotionally emotional] thought has no relation of reason to the thoughts which determine it, which exists in the last case and detracts from the attention given to the mere feeling." Further to the same point: "An incomplex thought can, therefore, be nothing but a sensation or emotion, having no rational character." (EP 1:45).

Here Peirce also adumbrated his later doctrine that Crude Interpretants are concreted universals, in the sense of reductively compelling the inexhaustible generality of nature and mind into "hide-bound" channels. As well, we see here the seeds of his fallibilism, Scotistic realism, and critique of both dogmatic rationalism and of bluff empiricism, the latter expressed in this crucial distinction between the dogmatically self-imploding "universal" of traditional forms of dogmatic philosophy (Apriorism) and Peirce's cosmical sense of "vague generality." True generality is a generative generality. "A conception, therefore, which was quite universal in every respect would be quite unrecognizable and impossible." 22

Peirce concluded this section on the Man-sign-the proto-expression of certain aspects of his later-phase trivalent semeiotics-by referring to Abstraction as power of Attention: "By the force of attention an emphasis is put on the objective elements of consciousness [Secondness]. It is in this respect different from an

21 Hume's treatment of "passions" in his Treatise of Human Nature and Inquiry Concerning the Principles of Morals (1751) may be thought to be another precedent to the ethical implications of Peirce's critique of Crude Emotionality. His "calm passions"-the "cool" as opposed to the "hot" passions-grounded his theory of "moral sentiment" in the universally valid perspective of the "impartial spectator." They function as mediating vectors in a sense comparable to Aristotle's sense of virtuous habits, while the "hot" passions tend to fall into the classification of the shortcomings of moral character.

22 "As in the conception of "Being," which is a sign-a thought, a word—not applicable to every sign, not primarily universal" - which Peirce finds "in the doctrine of Aristotle (whose categories are parts of speech) and of Kant (whose categories are characters of different kinds of propositions.)" (EP 1:45-46). This follows upon On a New List of Categories (1867) where Peirce opined that while Being "does not affect the subject, it implies an indeterminability of the predicate" [...] "but we have no propositions whose predicate is entirely indeterminate" [...] and "Thus substance and being are the beginning and end of all conception. Substance is inapplicable to a predicate, and being is equally so to a subject." (EP 1:2). 
immediate feeling [Firstness]; it comes down to being an effect on memory, or otherwise influencing a subsequent thought; abstractive attention is a matter of continuous quantity, which reduces in the last analysis to time, ergo does produce a very great effect on subsequent thought" [... such that it is] "the pure demonstrative application of a thought-sign" (EP 1:46). Attention, then, is aroused when the same phenomenon presents itself repeatedly in memory on different occasions, or in the same predicate in different subjects. "This attention is an act of induction, but it is an induction that does not increase our knowledge because our 'these' [indicated objects] cover nothing but the instances experienced. It is, in short, an argument from enumeration" [sampling]. "Attention [via quantitative induction] produces effects upon the nervous system. These effects are habits, or nervous associations. A babit arises, when, having the sensation of performing a certain act, or, on several occasions $a, b, c$, we come to do it upon every recurrence of the general event, $l$, of which $a, b, c$ are special cases. [...] Thus the formation of a habit is an induction, and is therefore necessarily connected with attention or abstraction. Voluntary actions result from the sensations produced by habits, or an instinctive action from our original nature" (EP 1:46-47).

For our purposes here, it is important to note that this "Man-sign" segment of Some Consequences of Four Incapacities also applied his concluding remarks as to why "singular and individual images" would be cases of "absolutely determinate" perceptions or affections-as in the Berkeley-Locke-Hume-Mill tradition of psychological empiricism (EP 1:47-50). Such an "absolute determination" of "particular images" is another form of "universality in every respect"-which, in another analysis, recurs also in Peirce's later critical considerations of the internally anancastic "concrete universal" of Hegel's Absolute Spirit. The true "association of ideas" consists-Peirce averred-in the "resemblances, contiguity, and causality" of inferential sign-transferences of the thing signified. "So, then, the association of ideas consists in this, that a judgment occasions another judgment, of which it is a sign. Now this is nothing less nor more than inference" [Thirdness] (EP 1:51).

Finally, Peirce's text proceeded on to discuss the fourth incapacity, "that the absolutely incognizable is absolutely inconceivable." Peirce encapsulated the positive implication of this "fourth principle" in another adumbration of his fallibilism and synechistic idealism,- - here, in the form of his logical distinction between "an ens relative to inward determinations, to the negations belonging to idiosyncracy, and an ens such as would stand in the long run." Consequently, "the very origin of the conception of reality"-he continued-essentially involves "the notion of a COMMUNITY, without definite limits, and capable of an indefinite increase in knowledge." And such being "the [idealistic] nature of reality in general," it follows that the "reality of mind" consists in the entire phenomenal manifestations of mind, that is, "is a sign resulting from inference" (EP 1:52).

All this early-phase writing implicated Peirce's critique of the limitation of Crude Emotionality. "It is hard for man to understand this"- he wrote in 1868- "because he persists in identifying himself with his will, whereas the real consistency of a man consists in the consistency of what he does and thinks"; but "consistency is the intellectual character of a thing." And "So thought is what it is, only by virtue of addressing a future thought [...] though more developed" (EP 1:54). Par excellence, these words of the young Peirce articulate a concept of logical consistency that goes 
beyond idiosyncratic emotionality. And, as we will see, it remarkably resonated with Aristotle's moral sense of the essence of humanity.

Peirce pressed the point. "It is hard for a man to understand this"-namely, that a man is a Man-sign!-_ "for he persists in identifying himself with his will, his power over the animal organism, with brute force." (But identification with one's own will is the mother of all Crude Interpretants!) In such a consummate moral resonance of the essay, Peirce concluded with yet another precocious variation on the basis of logicality or reasonable consistency. Referring to the "ignorance and error" of the individual Man-sign which is "only a negation," he cited Shakespeare's Measure for Measure (2.2.117-20): "This is man," he remarked,

.... proud man,

Most ignorant of what he's most assured,

His glassy essence. (EP 1:55).

Peirce presumably cited this passage from memory. This surmise would account for his omission of Shakespeare's ironical second line, "Drest in a little brief authority," which might have sowed further seeds for his critical exposure of the individuated Man-sign and a variety of doctrinal formulations of anthropocentric nominalism that occlude logical entry into his "Universe perfused with signs." 23

Peirce continued to stress this social theory of logical consistency in the concluding paragraphs of Grounds of Validity of the Laws of Logic: Further Consequences of Four Incapacities (1869) which culminated his Cognitive Series in the Journal of Speculative Philosophy. "Upon our theory of reality and of logic," he wrote, "[...] no inference of any individual can be thoroughly logical without certain determinations of his mind which do not concern any one inference immediately." (EP1: 80). He directly translated this epistemology of logic mediation into a moral ontology. "If a man has a transcendent personal interest infinitely outweighing all others, then, upon the theory of the validity of inference just developed, he is devoid of all security, and can make no valid inference whatever." Such a so-tospeak agathological theory of reality (combining the Good and the True) pointedly undercuts the logic of Crude Interpretant which features the "immediacy" of the reductive "universal" of individuated determination.

What follows? That logic rigidly requires, before all else, that

23 To repeat Peirce's career-text's key pronouncement cited above, itself an expression of the Third category: "It is a strange thing, when one comes to ponder over it, that a sign should leave its interpreter to supply a part of its meaning, but the explanation of the phenomenon lies in the fact that the entire universe,- - not merely the universe of existents, but all the wider universe, embracing the universe of existents as a part, the universe which we are accustomed to refer to as the 'truth,'- that all this universe is perfused with signs, if not composed exclusively of signs. Let us note this in passing as having a bearing upon the question of pragmaticism." (EP 2:394). 
no determinate fact, nothing which can happen to a man's self, should be of more consequence to him than everything else. He who would not sacrifice his own soul to save the whole world, is illogical in all his inferences, collectively. So the social principle is rooted intrinsically in logic. (EP 1:81).

Peirce goes on to amplify this kind of moral epistemology and ontology to draw the conclusion that a "psychological theory" which maintains that man cannot act without a view to his own pleasure is "based on a falsely assumed subjectivism." "The selfishness of man is based in large measure upon this false theory."24 "But"to the contrary- "just the revelation of the possibility of this complete self-sacrifice in man, and the belief in its saving power, will serve to redeem the logicality of all men" (EP1: 81).

With respect to Aristotle's pragmaticism of praxis, we should trace how Peirce's theory of the experiential consequences of belief blossomed into his concern to draw attention to the same kind of moral implications in "the conduct of life." He played out his synechistic logic in many applications, as for example in rejecting the principle of utilitarianism in favor of ascending motives for pure pursuit of "the majesty of truth" in Pearson's Grammar of Science (EP 2:57ff, 1901); and again, in Evolutionary Love (1893), very prominently in the context of framing the categorical foundations of evolutionary biology, expressing, contrary to "the gospel of greed" of Darwinism as well as the principle of hereditary pre-determinism, the gospel of agapic sympathy toward one's loved ones and neighbors (EP 1:352ff).

My overall argument here has been that Peirce's early-phase epistemological writings consciously implicated a moral ontology as well-linking reality, logic, and morals-while adumbrating a kind of neo-Aristotelian semeiosis of the praxis of Emotional and Logical Interpretants. We could ponder here further resonances between his early-phase expression of "proud man's" glassy essence (1868), of the moral grounds of validity of the laws of logic (1869), and his pronouncement in Immortality in the Light of Synechism (1893):

\begin{abstract}
Nor must the synechist say: 'I am altogether myself, and not at all you.' If you embrace synechism, you must abjure this metaphysics of wickedness. In the first place, your neighbours are, in a measure, yourself, and in far greater measure than, without deep studies in psychology, you would believe. Really, the selfhood you like to attribute to yourself is, for the most part, the vulgarist delusion of vanity (EP 2:2).
\end{abstract}

Mutatis mutandis, Peirce's statement also resonated with Aristotle's doctrine of the moral components of "Friendship" (philia) in the Nicomachean Ethics, components which are variations on his central doctrine of moral praxis enacted by the rational "mean" (mesotes, intermediate) on life's motivational platform of "feelings and

24 It is worth pondering Peirce's reprisal of Hume in this context. Hume's Enquiry concerning the Principles of Morals (1751) explicitly highlighted, only to roundly reject, the "selfish theory of morals" which he astutely recognized as the foundational theory in the tradition of Epicurus, Hobbes, and Locke. 
actions," "pleasures and pains." In this and other respects their philosophies prove to be reciprocally interpreting and mutually illumining, on a shared bottom line of what Ivo Ibri has conceptualized as the theoretical trajectory of a Kósmos Noetós.

\section{Aristotle's and Peirce's Kósmos Noetós of logical interpretant}

Peirce updated his theory of the "Man-sign" inscribed in Some Consequences of Four Incapacities (1868) in various later phases of his career. In What is a Sign? (1894), he reformulated his "three orders of signs" in the terms of Likenesses, Indices, and Symbols. Likenesses are the former essay's material signs which have no dynamical connection with the objects they represent; indices-signs are physically connected with their objects; the "symbol-using and Symbol-interpreting mind" has nothing to do with this connection, except remarking it "in its kind of idea," after it is established (EP 2:4-10). In precedent to that in A Guess at the Riddle of 1887-88, Peirce elaborated how the "symbol-using and symbol-interpreting mind" does so "in the interest in intelligibility," that is to say, "in the interest in the synthesizing "I think" — and this it does "[...] by introducing an idea not contained in the data, which gives connections which they would not otherwise have had" (EP 1:261).

Peirce's indexical signs are denotative of particular things, while the mind's symbolical operations are connotatively general. In the same essay, What is a Sign? of 1894, Peirce expressed this synechistic nature of symbols as follows:

Symbols grow. They come into being out of other signs, particularly from likeness or from mixed signs partaking of the nature of likenesses as symbols. We think only in signs. These mental signs are of a mixed nature; the symbol-parts of them are called concepts. If a man makes a new symbol, it is by thoughts involving concepts. So it is only out of symbols that a new symbol can grow. Omne symbolum de symbolo. A symbol, once in being, spreads among the peoples. In use and in experience, its meaning grows. Such words as force, law, wealth, marriage, bear for us different meanings from those they bore to our barbarous ancestors. The symbol may, with Emerson's sphynx, say to man, Of thy eye I am eyebeam. (EP 2:10).

Now with this distinction between the denotative connection of Indices to their objects and the connotative growth-potency of Symbols, it is possible to segue to Peirce's related theme of the commotional energies of Emotions in contrast to the interpretive role of Logical Interpretants. Significantly with respect to his neoAristotelian trajectory, he dealt directly with the indexical energies of self-centering Emotions and their concomitant manifestations as Pleasures and Pains in an extended passage of $A$ Guess at the Riddle (1877-88). ${ }^{25}$ In a segment devoted to a "psychological" application of his three categories Peirce elaborated his bottom line

25 Under the subheading of Chapter IV: The Triad in Psychology (EP 1:258-262) which followed upon his abductive "guess' concerning three foundational categories in One, Two, Three: Kantian Categories (EP 1:242-244) and in the opening "Trichotomy" section of "A Guess" (EP 1:247-56). 
differential analysis of "three radically different elements of consciousness, these and no more": "Immediate feeling is the consciousness of the first; the polar sense is the consciousness of the second; and synthetical consciousness is a consciousness of a Third or medium." (EP 2:260). This seminal passage arguably framed a doctrine of Emotions in tandem with discussion of putative "immediate feelings," though "in the objectionable sense of pleasure and pain"-such that, in addition to the primary sense of Feeling as the absolutely fresh and spontaneous presence of immediate consciousness, it underwrites a secondary sense of Feeling as Crude Emotion.

To this end in "A Guess," Peirce first characterized the Thirdness of Cognition as the form of genuinely synthetical inference-the dimension of mental growth in the learning process-which "it does by introducing an idea not contained in the data"-declaring it to be the "undegenerate and really typical form" of synthetical consciousness. ("The work of the poet or novelist is not so utterly different from that of the scientific man" (EP 1:261)). He followed this with descriptions of the two types of degenerate synthetical consciousness, either of which involves what is tantamount to "Emotions" in the sense of "secondary phenomena." Such "Emotions" as secondary feelings are "passive" - (or "pathetic," as we will further see in Aristotle's usage of the Greek term pathê, and which calls to mind Kant's employment of the "pathological" nature of heteronomical desire)— in that such passive emotions involve "feelings of compulsion."

Reset in Peirce's logician's terms, (1) the first degenerate type of Emotion is that of "external compulsion," as in "association by contiguity," or, more generally, "whenever we are compelled to think certain things together or nearer than others"; (2) synthetical consciousness "in a second degenerate degree, corresponding to intermediate thirds," is where we internally think different feelings to be alike or unlike; while immediate feelings in themselves cannot be compared, the mind becomes "internally compelled to synthesize or to sunder them"- this is the kind of synthesis that appears in traditional empiricism's "association by resemblance."

Peirce here availed himself of Hume's key rubrics for the "association of ideas," namely of contiguity, resemblance, and cause and effect, while linking the first two to the status of degenerate forms of feelings/perceptions. But backtracking to the beginning of this passage in "A Guess" - on the psychology of "Feelings, Knowing, and Willing"- we gain clearer purchase on Peirce's parsing of the difference between Feelings in the primary categorical sense and of Feelings qua Emotions in the second categorical sense. Bypassing Hume, Peirce starts out with reference to "Kant" and the doctrines of "most psychologists" concerning the "feelings of pleasure and pain." He says, in reference to Kant's doctrine, that there is no good reason for Kant's giving such a peculiar place as he did to "pleasure and pain," as if they had no resemblance to anything else we can feel. "Pleasure and pain" are "nothing but secondary sensations, or feelings produced by feelings, or whenever the latter reach a certain degree of subjective intensity, that is, produce a certain amount of commotion in the organism" (EP 1:258). ${ }^{26}$ Thus, while Feelings in the primary categorical sense are "immediate and instantaneous," having "no relation to the past or the future"

26 While bypassing Hume in the present context, we have seen that Peirce elsewhere characterizes Hume's doctrine of the "force and vividness of immediate perceptions" and of the progeny of his followers in the same terms. 
in their "fleeting" instantiation of "absolutely immediate consciousness, or feeling," the mind may work up "resemblances" by a secondary mental energy of "memory." Such re-member-ed resemblances are "associations of feelings" that "[...] suppose a dismemberment and re-composition which is totally foreign to the immediate, and in the second place, memory is an articulated complex and worked-over product that differs infinitely and immeasurably from feeling" (EP 1:259).

We shall shortly see that Peirce's fine-tuned semeiotic configuration of the difference between the First-quality of Immediate Feeling, and the Second-function of Crude/Emotion together with the latter's attendant feelings of Pleasure and Pain was substantially corroborated by William James' empirical descriptions in his Principles of Psychology (1890) — and that the analyses of both Peirce and James have their classical provenance in Aristotle.

Peirce expressed this differential configuration in, among other places, The Basis of Pragmaticism in the Normative Sciences (1906):

Esthetic good and evil are closely akin to pleasure and pain. They are what would be pleasure and pain to the fully developed superman. What, then, are pleasure and pain? [...] They are secondary feelings or generalizations of such feelings - that is, of feelings attaching themselves to, and excited by, other feelings. ${ }^{27}[\ldots]$ To use the old consecrated language, pleasure is the feeling that a feeling is 'sympathetical,' pain, that it is 'antipathetical.' The feeling of pain is a symptom of a feeling that repels us; the feeling of pleasure is a symptom of an attractive feeling. Attraction and repulsion are kinds of action. Feelings are pleasurable or painful according to the kind of action which they stimulate. In general, the good is the attractive,- - not to everybody, but to the sufficiently matured agent; and the evil is repulsive to the same. Mr. Ferdinand C. S. Schiller informs us that he and [William] James have made up their minds that the true is simply the satisfactory. No doubt, but to say 'satisfactory' is not to complete any predicate whatever. Satisfactory to what end? (EP 2:379).

In this passage Peirce arguably repeated the gist of Aristotle's Nicomachean Ethics concerning passive Feelings (pathé, emotions, passions) and efficient Actions (energeia) with their concomitant incentives of Pleasure and Pain (bedonê, and lupus or algos - the latter sometimes translated as "distress"). In his later-phase classification of the Normative Sciences, Peirce's set "Esthetic good and evil" at the basis of "Ethical good and evil," which in turn reset the a priori categorical ground for the Symbolical-Logical-Interpretant form of the mind.

Now fast-forwarding to his The Neglected Argument for the Reality of God (1909) Peirce again came back to the psychology of pleasures and pains in his "Musement" on the "Three Universes":

27 Here Peirce gives the example of a toothache, where pain accompanies the simple quality of the toothache. 
Among the more purely psychological questions, the nature of pleasure and pain will likely to attract attention: Are they mere qualities of feeling, or are they rather motor instincts attracting us to some feelings and repelling others? Have pleasure and pain the same sort of constitution, or are they contrasted in this respect, pleasure arising upon the formation or strengthening of an association by resemblance, and pain upon the weakening or disruption of such a habit or conception? (EP 2:438).

Peirce's query here will also be seen to trace back to Aristotle's front and center discussions of the supervenience of "pleasures and pains" on "feelings and actions" in the Nicomachean Ethics. ${ }^{28}$

But here, reference to William James' empirical psychology (presumably known to Peirce) will thicken up the discussion. James penned many rich descriptions in his two-volume Principles of Psychology (1890) that virtually dovetailed with Peirce's analyses of the difference between Crude/Emotional and Logical Interpretants. In Chapter XXI, "The Perception of Reality," James in fact redescribed, in empirical terms, the topic of "The Influences of Emotion and Active Impulse on Belief" whose very chapter title, as well as contents, dovetailed with Peirce's "The Fixation of Belief" of 1877. James predominantly described "Belief" in terms of the bodily and emotional commotions which "exciting perceptions and ideas bring forth." He arguably identified the equivalent of Peirce's sense of Crude/Emotional Interpretant in the terms of M. Renouvier's equation of "passion" and "mental vertigo": "[...] the object of passion makes us deaf to all but itself, and we affirm unhesitatingly." (JAMES, 1890, 308-309). James expanded the theme in the same chapter's next section, "Belief in Objects of Theory" that was also directly germane to Peirce's Methods of Fixing Belief.

Then, in the sequent chapter XXVI on "Will," James took up the theme of "Pleasure and Pain as Springs of Action" in terms that expressed the physiology and psychology of the efficient supervenience of Feelings in terms also germane to Peirce's semeiotic doctrine of Emotional Interpretants as categorical Seconds. There James—and seemingly against his final verdict of truth as "satisfaction"?- - significantly rejected the classic theory of the primacy of the feeling of pleasure predicated in the Epicurean equation of virtue with pleasure-Epicurean doctrines that were contemporaneously rejected by Aristotle and the Stoics (JAMES, 1890, p. 549-551). In volume two's chapter XXII on "Reasoning" James turned to distinguish in empirical terms what he calls the "Recepts" of the "unproductive," "purely practical," "contingent resemblances" of ideas, in contrast to "sagacious reasonings" occupying another level of "meanings" as "teleological essences" in open-ended "productive" associations of ideas via classification and conceptualization. "Recepts," James avers, are "simple associations of concretes," consisting in "concrete objects of past experiences merely suggesting each other." Such "Recepts" are "concreted universals"—or we might say "reductive universals"-in the sense of solidifying our "stuck" habits and hide-bound prejudices; they are reductively "re-productive" in their net effect of re-conforming with and re-confirming past experiences, as distinct from conceptual reasoning that is forwardly "productive" (Ibid., p. 319-330, 350). James penned similarly empirical

28 Nicomachean Ethics VII, 11-14, and X, 1-6. 
descriptions in chapters on "Habituation," "Instincts" and "Emotions" which featured such bottom line themes as "Instinctive reaction and emotional expression shade imperceptibly into each other," and "Emotion is a consequence, not the cause, of the bodily expression" (Ibid., p. 442, 449).

Let us now return to Peirce. In framing his semeiotic doctrine of the difference between the indexically denotative "concreted universal" of Crude Emotionality and the open-ended connotative generality of Logical Interpretant, Peirce in many contexts significantly alluded to Aristotle's doctrine of Efficient and Final Causation. In "The Seven Systems of Metaphysics" (1893) he astutely noted that Aristotle does not always conflate efficient (energeia) and final (entelecheia) causalities:

The doctrine of Aristotle is distinguished from substantially all modern philosophy. In places Aristotle has glimpses of a distinction between energeia and entelecheia by its recognition of at least two grades of being. That is, besides actual reactive existence [Secondness], Aristotle recognizes a general being, an esse in potentia, or as I like to call it, an esse in futuro [Thirdness] (EP 2:180, 1903). ${ }^{29}$

Now this astute reference to Aristotle in Seven Systems of Metaphysics (1903) followed upon Peirce's previous penned On Science and Natural Classes (1902), where he averred:

It is [...] a widespread error to think that a 'final cause' is necessarily a purpose. A purpose is merely that form of final cause which is most familiar to our experience. The signification of the phrase 'final cause' must be determined by its use in the statement of Aristotle that all causation divides into two great branches, the efficient, or forceful, and the ideal, or final [e.g., De Partibus Animalium, 639b12-15, FN 8 in EP 2:515]. If we are to conserve the truth of that statement, we must understand by final causation that mode of bringing facts about according to which a general description of result is made to come about, quite irrespective of any compulsion for it to come about in this or that particular way; although the means may be adapted to the end. The general result may be brought about at one time in one way, and at another time in another way. Final causation does not determine in what particular way it is to be brought about, but only that the result shall have a certain general character. Efficient causation, on the other hand, is a compulsion determined by the particular condition of things, and is a compulsive action to make the situation begin to change in a perfectly determinate way; and what the general character of the result may be in no way concerns the efficient causation. [... Here Peirce provides an example of firing a bullet to shoot an eagle on the wing - the fired bullet is turned over to "the stupid efficient causation," "simply obeying orders blindly," in

29 Cf. EP 2:552, which indicates that for "substantially" in his published text Peirce initially referred in a manuscript version to "Schelling and myself" as counter-examples in modern philosophy! 
the "bic et nunc"'] It is true that the force of the bullet conforms to a law; and the law is something general. But for that very reason the law is not a force. [...] Thus, the relation of law, as a cause, to the action of force, as its effect, is final, or ideal, causation, not efficient causation. (EP 2:120-121).

Astutely, then, Peirce brought to bear his trivalent categorical terms to correlate the "secondary phenomena" of "pleasures and pains" attendant upon Aristotle's "feelings and actions" with the efficient causation of Crude/Emotional Interpretant, in distinction from the in futuro final causation of the Logical Interpretant. Played out on its own level, the "concreted universal" of the former effectively suffocatessucks the semeiotic oxygen out of the air of - the open-ended dialogic trajectories of energetic-entelic outcomes of inquiry and the conduct of life. The Crude/Emotional Interpretant is a kind of materialist Leibnizian monad that "has no windows" (and the doors are slammed shut)—that is to say, it denotatively pre-contains all its predicates. In contrast, our semeiotic dialogues comprised of connotative Logical Interpretants go on incessantly in connatural "Thou" growth-relations in respect to our natural and social environments, as well as, already and always, in our "Thou" symbolical streams of internal private thoughts.

But again, such a Peircean doctrine of energetic-entelic outcome of the Logical Interpretant is found in nuce in the applied intentionality of Aristotle's doctrine of rational praxis in his Nicomachean Ethics (and his other ethical treatises) as well as functioning as the front and center concept of his broader range of philosophic treatises based on his doctrine of the "four causes" (formal, material, efficient, final). Peirce also focused on the "Prince of Philosopher's" recognition of a fifth cause, namely, that of Chance (tychê), in formulating the first cosmological category of his tychistic universe. (We should regard this as one of Peirce's most astute observations, generally unrecognized in the literature.) Moreover, taking into account Aristotle's multifaceted expressions of the organic "coincidences" of Formal, Efficient, and Final Causes in tandem with the causation of Chance, my suggestion is that we here have the essential categorical components of both Aristotle's and Peirce's framing of a theory of "Reality" as a Kósmos Noetós—that is, as I will develop further, of the "Universe perfused with signs" itself as Logical Interpretant. ${ }^{30}$

But here, further to Peirce's semeiosis of Crude/Emotional vs. Logical Interpretant, in the subsection on "Personality" of his central metaphysical essay, The Law of Mind (1892), Peirce concluded to the concept of "Personality" as entailing a "coordination" and "teleological harmony of ideas"- "not a mere purposive pursuit of a predetermined end; it is a developmental teleology" (EP 1:331). This concept of "developmental teleology" harvested the seeds of the same essay's articulation of the "One Law of Mind," namely that "ideas tend to spread continuously, affecting others, and gaining in coordinated generality." His ensuing metaphysical essay, Evolutionary Love (1893) carried the same doctrine of "developmental teleology" further in quasi-theologizing terms pertinent to parsing the kinds of natural and cosmic evolution in the three categorical terms of simple Darwinism, of hereditary anancasm, and of agapistic growth.

30 As elaborated in RLT 242-268. 
In The Law of Mind (1892), Peirce articulated the basic components of this central analysis of Personality as his "[...] synechistic philosophy, as applied to mind." (EP 1:333, Peirce's emphasis). He did so via a roll-out of subheadings on "Individuality of Ideas," "The Continuity of Ideas," "Infinity, and Continuity in General," "That Feelings Have Intensive Continuity," "That Feelings Have Spatial Extension," "Affections of Ideas," "Ideas Cannot be Connected Except by Continuity," "Mental Life Follows the Forms of Logic," and "Uncertainty of Mental Action" (EP 1:314-328). These were Peirce's astutely considered foundational ingredients of the concept of Personality that theoretically comprised the concept of "developmental teleology" tout court for all consequent epistemic, ontological, and semeiotic generalizations of his symbol-natured Kósmos Noetós.

But again, the historian of philosophy must note that Aristotle's Nicomachean Ethics wrote the classic script for precisely the same concept of Kósmos Noetós, though in its particular focus on Ethics and Politics as personal and political developmental teleologies, respectively. Peirce's Fallibilism, to be sure, diverged from Aristotle on the latter's doctrine of the theoretical (theoria) employment of reason that is modeled on the demonstrative certainty of classical geometry; but he converged with Aristotle on the practical (praxis) employment of reason not only in regard to Ethics and Politics but the entire gamut of the Arts and Crafts. Such a strain of Aristotelian praxis explicitly entailed "pragmatic" methods of fallibilistic inquiries and outcomes along the gamut of the Practical Sciences and the Arts and Crafts; for Peirce, the deliberate co-effect of this kind of pragmatistic pragmatism works to jettison the classical model of a priori demonstrative certainty (not to mention all its modern "Cartesian" variants). ${ }^{31}$

By pragmatisticpragmatism I refer to Peirce's rescuing of his "kidnapped" earlyphase Pragmatism, which James narrowly cashed out in action, into his (Peirce's) later-phase sense of open-ended, ramifying and proliferating, conceivability and conduct-ability (EP 2:334-5, and passim). For Peirce, "intellectual concepts" play vitalistic roles, functioning as activating Logical Interpretants in the Kósmos Noetós. The affine precedent of Aristotle's realistic sense of moral praxis is already involved here. It is arguably built out of a conception of "habituated character" (bexis, literally, "actively having, possessing)" that functions as a self-activating "condition," "state," "character," "second nature"—or developmental teleology!-of a self-reliant (self-strengthening and self-resilient) virtuous person. A vicious person acquires a corresponding "base" hexis of character.

Aristotle's bexis in this sense is distinguished from "capacity" (dynamis, dynatos), which may or may not be activated, and from passive "feelings" (pathé) and the "work" (ergon) of specific "actions" (energeia). His concept of the "mean"

31 The perhaps most remarkable "Cartesian" example is Kant's text that is so predicated on a basic distinction between the theoretical (theoria) and the practical employment (praxis) of reason: Kant carried these Aristotelian distinctions over into his transcendental analyses of the "fundamental concepts of philosophy," namely of Nature and Freedom. But, as we have already noted, Aristotle did not write philosophy as transcendentalist critique in the Kantian vein. Aristotle was, rather, proto-Peircean in framing the objective domains of experiential praxis entailing a decidedly pragmatistic pragmatism and corresponding developmental teleology comprising the "work in progress" processes of Logical Interpretant in the "rational conduct of life." 
(mesotes, intermediate) of rational conduct functions in the proceptive role of the normative Logical Interpretant in its rational accountings of "feelings and actions" in the "good" soul's dispositional intentionality towards realization of "Happiness" in a "complete (entelaios) life." Aristotle's key articulation of the "mean" (mesotes, intermediate) in the nutritive and appetitive soul's tendencies to "excess and defect" precisely featured such a notion of mediating interpretant that is simultaneously efficient-and-entelic in "resolving" the allurements and resistances-the "pleasures and pains" - that are ubiquitous in the ongoing challenges of life into virtuous outcomes. ${ }^{32}$

Now, the Nicomachean Ethics showcased the degenerate allurements and distressful predicaments of emotional life quite in precedent to James' descriptions of the gamut of passive emotions that are grounded in physiologically and neurologically grounded trigger-instincts and their "stuck" emotional counterparts in appetitive actions of the "base" type. Aristotle's sense of the active dispositional state (bexis) of the "good" soul conceptualized a generative continuum comprised of the polar extremes of excess and defect which are rationally mediated by a "middle" range of "measured" virtuous outcomes in the continued progress of the rational part of the soul's character development. His doctrine concerning the deliberative choice and decision required to enact the "mean" between behavioral excesses and defects with their attendant pleasures and pains, functioned precisely as the energetic-entelic activity of the Logical Interpretant which catalytically transforms the efficient energies of "emotions and actions" into its own finality of esse in futuro character development.

Aristotle's model of a person's "habituation" in virtue or vice was patently "developmental," and, in my interpretation here, arguably the classical provenance to Peirce's sense of non-predetermined final causation (entelecheia) that recognizes the tychistic nature of experience. Neither Aristotle's self-activating condition of character ( hexis) nor Peirce's sense of developmental personality predicates a "oneoff" indexical sinsign, or semeiotical Second-category, "feeling or action." Rather, each involves the Logical Interpretant of the Third category of Representation. Thus again, we reach the conclusion that Aristotle's doctrine of the entelic energy of a person's virtuous character (bexis) through the deliberative and decisive activity of the mesotes in the rational part of the soul's self-activation and self-correction, preconfigured Peirce's more generalized senses of the "Law of Mind" and even of the "Law of Liberty" framed in the tychistic-synechistic Thirdness of a Kósmos Noetós. Pertinent to both moral and cosmological conceptualizations, in the tychisticexistential world of human potential, the mesotes plays the role of noetic "risk management." Peirce astutely generalized the same virtuous - "vitalistic"—activity as a "learning process" in the connatural semeioses of nature and mind partaking of the character of the Kósmos Noetós as a "Universe perfused with signs."

Now in such ontological-semeiotic terms we have already re-conceptualized Peirce's pluralistic and synechistic "One Law of Mind" as marshaling components

32 Cf. Whitehead's conceptualization of the same entelic process in the terms of the "subjective-superjective" character of the "actual occasions" of experience; I also draw upon Justus Buchler's comparable concept of "proceptive judgment" to express the actively prospective character of both Aristotle's and Peirce's pragmatistic pragmatism. 
of the "individuality, continuity, and affectability of ideas" to render a bottom-line sense of developmental Personality. Once again, arguably its classical precedent was the Nicomachean Ethics's notion of the rational soul's "education" (paideia), which begins with a good upbringing from youth and matures in qualitative enactments of the mesotes in the course of a "complete life" of both intellectual and (craft-like) moral accomplishments. ${ }^{33}$

Aristotle's and Peirce's comparable senses of the vitalistically mediating function of Logical Interpretants is essentially qualitative, not quantitative, functioning as a form of uberously abductive, not merely re-iteratively inductive, nor again of deductive, inference. We have already seen the seminal reasons of this doctrine at work in Peirce's epistemological doctrine of the Symbol-interpreting Man-sign's mediating function expressed in Some Consequences of Four Incapacities (1868); and we noted the same essay ended on a moral note of critiquing "proud man's" "glassy essence." Aristotle's like-minded semeiosis, expressed in reference to the mediating function of the moral mean, takes the measure of the potential outcomes of qualitative conduct contributing to the eudaimonic generality of a "complete life" in the face of the always confronting occasions for idiocentric outcomes of "emotions and actions" on the immeasurable contingent platform of "pleasures and pains."

Correspondingly, and in his larger construction of semeiotic ontology, Peirce's Logical Interpretant "conducts" the contingent occasions of life into outcomes of "energetic reasonableness." (The analogy with the conductor of an orchestra who proceptively controls the energetic outcome of a symphonic ensemble comes readily to mind). Applied to the spheres of human conduct, each of our philosophers, Aristotle and Peirce, rendered versions of rationally perseverant character (bexis) in the pragmatic and performative matters of life. (Peirce referred to the Thirdness of pragmaticism as "Peirce-sistence" and "Peirce-severance"-both words connoting a "vital confidence" in the sequent future).

Now let us see Aristotle's contribution to this philosophic paradigm. Book One of the Nicomachean Ethics opened splendidly with allusion to his architectonic and differential analysis of the various of kinds of "goods" (teloi, final causes, ends, aims, goals, outcomes, purposive functions) that become subject matters along the gamut of theoretical sciences (Physics, Mathematics, Metaphysics), of agential human sciences (Politics and Ethics), and of the multiform Arts and Crafts. The philosopher surveys a virtually inexhaustible variety-indeed an always proliferating variety - of human purposes and goods in both receptive and proceptive modalities of human intelligence. In assignable degrees, some combinations of goods and purposes are instrumental and intermediate, while others are self-sufficient and final. Here already Aristotle lays the basic platform of his pragmaticism in his dictum that, in Ethics and Politics, "theoretical precision is relative to the subject matter," and cannot be deduced a priori. In the epistemology of the practical sphere of agency (praxis), "the educated person" must be satisfied to "project the truth roughly and in outline" since the moral subjects are subject-

33 In his youth Peirce was attracted to Friedrich von Schiller's variation on Aristotelian paideia in his Letters on the Aesthetic Education of Man, 1795. 
superjects of praxis, namely, of "things that hold good usually [but not universally]; and this is different from the demonstrative method of the mathematician" (NE 1049b20). For the study of the range of normative concepts pertinent to ethical and political conduct, it is a matter of "education" (paideia) of the practical part of the soul. The student of Ethics should have reached years of discretion; for youth is rather driven by feelings, that is, "by pleasures and pains" (generally, a regimen of pleasures from childhood on). Youthfulness per se, however, is not the bottomline issue; it is rather "immaturity" —or in Peirce's term, "crudity" —of character that only clots over time (NE 1095a10).

Accordingly, in respect of the practical development of a virtuous personality, Aristotle identified Happiness (eudaimonia) as the ultimate aim and fulfillment of the "good life" - that is, "living well and doing well" - the study of which Aristotle parses into Politics and Ethics as separable but interconnected sciences of the human good. In this opening context of the Nicomachean Ethics he virtually wrote the script for Peirce in fashioning a version of Logical Interpretant that rejects the putative "concreted universal" of the Emotional Interpretant which sucks all the buman semeiotic oxygen out of the air, shutting down the ongoing dialogic of ideas and stunting the growth-potential of an individual's or a community's habits of belief. What is thus crucially germane to our comparison with Peirce, Aristotle's Book One straightforwardly critiqued types of reductive "universals" proffered by his predecessors, Plato and Socrates; he then linked Socrates' version of Plato's "unqualified universal" of moral character to Socrates' progeny in the Cynic schools - as well as targeting the rhetorical versions of a so-to-speak "deconstructive universal" that was the stock in trade of the aporetic dialectic practiced by Plato's and Aristotle's rivals, the $5^{\text {th }}$ and $4^{\text {th }}$ century Sophists.

First, citing Plato's doctrine of the difference between arguments "from and toward first principles," Aristotle urgently rejected Plato's transcendent Idea of the Good that is "known without qualification," subsisting in some noumenal realm "apart." "Presumably"-Aristotle insisted-"we ought to begin from things known to us." ${ }^{4}$ In net effect, Aristotle critiqued Plato's Idea of the Good as reductively de-realizing the particular efficient and final causalities of human motivation along the entire gamut of the sciences, arts, and crafts, including the practices of ethical and political life. Rather, Plato's ethics and politics converged into one denotatively authoritarian "concreted universal" in the form of the elitist and hierarchical politics of the Republic. ${ }^{35}$

Now, to the same end, Aristotle repeatedly critiqued the historical Socrates of Plato's early Dialogues in various contexts of the Nicomachean Ethics, regarding him as aporetic interlocutor who taught that "Knowledge is Virtue"-another binary and hierarchical conception of good and bad in which "Knowledge" functions to

34 To bring Peirce back into the picture, Plato's "unqualified" Idea of the Good has its final reductive apotheosis in Hegel's apriorism of the "Concrete Universal" of Absolute Spirit. This description was the drift of Schelling's critique of the "negative philosophy" of the "modern" philosophers extending from Descartes on to Kant and culminating in Hegel.

35 We might note in passing that the "political scientists" of Hitler's Germany appropriated the theory of the Platonic philosopher as occupying an elitist top governorship of a stratified human moral order envisioned for the Third Reich. See KIM, 2018. 
exhaust the prudential field of virtues by relegating all non-virtuous practices to "Ignorance." 36

A further pragmatistic critique of Socrates' teaching followed in respect to Socrates' followers in the Cynic School, whose members were said to teach "a philosopher's paradox," namely by claiming and acting out that virtue alone is sufficient for happiness (NE 1145b23). Though it could equally apply to the Epicurean principle that prioritizes pleasure over virtue-c "pleasure" in the life of ataraxy of soul-Aristotle argued that while "every state of soul is naturally related to and about whatever naturally makes it better or worse" - and "pleasure and pain make people base, from pursuing and avoiding the wrong one, at the wrong time, in the wrong ways"-he appears here to further reference the Cynics, if not also Socrates, in averring: "These [bad effects of pleasure and pain] are the reason why people actually define the virtues as ways of being unaffected and undisturbed [by pleasures and pains]. They are wrong, however, because they speak of being unaffected without qualification, not of being unaffected in the right or wrong way, at the right or wrong time, and the added qualifications." (NE 1104b19-23, emphasis added). These critiques are variants on his original rejection of Plato's "unqualified universal."

As yet another variant of his critique of Plato's "unqualified universal," Aristotle pegged Socrates' disputational counterparts, the Sophists, as teaching another binary logical form of arresting universality in their employment of "rhetorical paradoxes" in which dialogic encounters result in "unresolvable puzzles": "for thought is tied up, whenever it does not want to stand still, because the conclusion is displeasing, but cannot advance, because it cannot solve the argument" (NE 1146a23-26). (Aristotle further critiqued the Sophists' credentials to give moral and political instruction in the final chapter of Book Ten of the Nicomachean Ethics. (NE 1146a30-33, 1180b351181a12)). In Book VII he also referred to the Sophists' "paradoxical universal" in a context of discussing Foolishness combined with Incontinence. The passage can be read as another provenance (epistemological and moral) to Peirce's famous description of "matter"-here "emotional matter" - as "partially deadened mind," that is, "mind hide-bound by habits," when in the sequel Aristotle pressed the point that the "solution" of Sophistical "thought tied up" must come with a continent person's power of rational decision to "loose the binding" (NE 1146b6-7). ${ }^{37}$

For Aristotle, then, the thought-forms of Plato, Socrates, the Cynics, and the Sophists, were all "tied up," that is, consist of "hide-bound universals," and therefore

36 NE 1144b10, 1147b15. "Socrates, however, was busying himself with ethical matters and neglecting the world of nature as a whole but seeking the universal in these ethical matters, and fixed thought for the first time on definitions; Plato accepted his teaching, but held that the problem applied not to sensible things but to entities of another kindfor this reason, that the common definitions could not be a definition of any sensible thing, as they were always changing" (Metaph. I, 6, 987b1).

37 By no particular stretch of the speculative imagination it is natural to read Aristotle's critique of the Sophists' kind of internally deconstructive universal as applying to the, e.g., contemporary French postmodern binary logic of the "presence and absence" of signifiers without signified. In his Metaphysics Aristotle likened the task of following the Sophists' arguments to "tracking flying game" (Metaph. 4.5.1009b37). 
became targets of his pragmaticism of praxis which functions to open the semeiotic field of "added qualifications" in the ongoing learning processes of the developmental teleology of moral conduct. They proffered "crude," that is to say, "uncooked" or "concreted" versions of Crude/Emotional Interpretants of the conduct of life. Such reductively politicized theories are of course the classical paradigms of many of the ideological practices of contemporary life. Arguably they should be classified under Peirce's "degenerate" form of fixing belief by Apriorism-archetypes of dualistic epistemological, political, and ethical theories exposed as such by Aristotle's and Peirce's comparable senses of tychistic synechism set in the free semeiotic openness that is discoverable in the connatural "energetic reasonableness" of symbolical signinterpretation.

Now once again returning to Book One of the Nicomachean Ethics, Aristotle pressed the ethical dimension of Habituation, that is to say, of moral and intellectual Education (paideia) via entelic outcomes over the chrono-logical course of a "complete life" (NE 1098a19). Read through Peirce's sense of the non-determinate generality of final causation, Aristotle's concept of "a complete life" arguably looms as one of the most penetrating concepts in the history of philosophy. It entails that, assuming a person has a right sort of nature, moral education (paideia) will train him or her by habituation (ethismos) to acquire the right habits (ethos) of self- and hetero-criticism in the uses of "pleasures and pains" as incentives and disincentives of rational conduct. Therefore, concomitantly, habituation includes proceptively activated tendencies of acquired character (bexis) to feel pleasures and pains, and to have other feelings and to act, "in the right way," as a precondition for genuine virtue. But again, "in a complete life," characterized by the predicate of "selfsufficiency" that is not limited to an isolated individual, but to what "suffices also for parents, wife, children, friends, and fellow-citizens" (NE $1099 \mathrm{~b} 17$ and passim).

In a nutshell, the lifelong acquisition of the "best and finest goods" of life consists in actively possessing and using - that is to say, in a character formation (bexis) that is increasingly self-actualizing in real time. In Aristotle's famous lines: "And just as Olympic prizes are not for the finest and strongest, but for the contestants-since it is only these that win-the same is true in life; among the fine and good people, only those who act correctly win the prize" (NE 1099a4-6).

Thus, in Aristotle's ethical application of Kósmos Noetós, "to act correctly" means to transmute the instinctual and emotional motivating appetencies of "feelings and actions" into James' "productive tendencies of reasoning" and into what Peirce has prioritized as symbolical Logical Interpretant. He set the "final cause" of Happiness (eudaimonia) as the most general, most "productive" concept of character formation - that is to say, as the normative gold standard for the excellent (spoudaios), fine (kalos), and civilized (eleutherios) life of intellectual and moral accomplishment.

In his own comparable way, Peirce addressed the conceptual obligations of the summum bonum in his later-phase writings centering on Phenomenology, the Normative Sciences, Pragmaticism (as "the Logic of Abduction"), and related themes in explication of the nature of heuristically significant meaning and conduct. Influenced by Schelling's concept of Positive Philosophy, Peirce's non-Hegelian "energetic reasonableness" re-predicated Aristotle's normative ideal of qualitative eudaimonia in the more expansive terms of a sublimely "admirable" worldview. 
Thus he arguably parsed Aristotle's gold standard of eudaimonia into the "admirable" principle of cosmical and human "reasonableness" framed in prioritized normative terms of Esthetics, Ethics, and Logic, and produced a poetico-religious symbolism of these in articulating the contemplative potency of "Musement" in A Neglected Argument for the Reality of God (1908) and in a like potency of the "smile of Beauty" in An Essay toward Improving Our Reasoning in Security and Uberty (1913).

Peirce's kalagothological worldview featuring a three-dimensional "Universe perfused with signs" was itself his "uberous" predication of the "reason-able energy" of the Logical Interpretant functioning as mediating vector of such qualitative accomplishments. His Kósmos Noetós is a hyperbolic growth-process in symbolic Thirdness synthetically inclusive of the inexhaustible First and Second dimensions of qualisigns and indices. Shared with Aristotle's conception of the mediating functioning of the reasonable mean (mesotes, intermediate) between the polar extremes of excessive and deficient outcomes, the Logical Interpretant functions as the semeiotic form of non-degenerate, productive inference in the Kósmos Noetós of Qualitative Induction. We have seen that the seminal seeds of such a combined epistemological and moral ontology already began to sprout in the logical socialism of Peirce's early writings on "man's glassy essence," in Some Consequences of Four Incapacities (1868), and Grounds of Validity of the Laws of Logic (1869).

Now back to Aristotle. Aristotle's foundational sense of the moral mean (mesotes, intermediate) which mediates between the "vertiginous" (in James' word) extremes of "feelings and actions" - and their corresponding outputs of degenerate "pleasures and pains" - arguably functions as the likeminded form of Qualitative, not simply Inductive, synthetical inference in the connatural dimension of rational human conduct. Thus, his ethically generative and re-generative entelechy of the mean in the ongoing momentum of a virtuous life amounted to a habituated employment of voluntary, deliberative, and decisive activities in qualitative accomplishments. ${ }^{38}$ In such terms, Aristotle's classical exemplar of moral habituation resonates with Peirce's form of perceptual judgment functioning as continuously unfolding conceivable generality — or again, with perceptual judgment as the abductory form of Qualitative Induction in futuro, having a so-to-speak synechistically superjective character, in the vital trajectories of theoretical, agential, and craft life of the rational soul. (The bexis of a "base" soul goes in an opposite trajectory).

In Book One of the Nicomachean Ethics, Aristotle also broached the gold standard of "Happiness" (eudaimonia) by asking "how is it achieved"-by theoretical learning, by habituation, by some divine fate (or anancastic decree), or by fortune (that is, by "chance"). He astutely answers that if by the gods, they would have given

38 In this writer's estimation, there is no greater civilizational legacy passage in the entire history of philosophy than the comprehensive typology of moral virtues and vices formulated in the Nicomachean Ethics, Book Three, chapters 6-9 and Book Four, which employs the Logical Interpretant of the "mean" (mesotes) to characterize courage, temperance, liberality, munificence, high-mindedness, good temper, sociability, sincerity, tasteful ready-wit and tact, modesty, proper indignation, and justice, and their corresponding excesses and deficiences. The passage has another list of vices that do not admit of a mean, such as malice, shamelessness, envy, adultery, theft, and murder. In the world's greatest poetical work, Dante built the 100 cantos of his Divina Comedia, and particularly of the Inferno and Purgatorio, on Aristotle's classifications. 
it; and, if by nature, more widely shared. Since happiness is a certain accumulative activity, it is not the result of fortune, either. A child is not happy, but congratulated for anticipated happiness in a "complete life" of virtue-a "complete life" because life includes many practical reversals of fortune, good and bad, a prosperous person (such as Priam in the story of the fall of Troy) not excepted.

Book Two (chapter one) then expanded Aristotle's ethical inquiry concerning the maturation of personality, saying that "virtue of thought" arises mainly from teaching, therefore requiring experience and time, while "virtue of character" (êthos) arises from habit (ethos), which gives its name "ethical." "And hence it is clear that none of the virtues arises in us naturally [...] "Rather, we are by nature able to acquire them, and we are completed by habit" ("complete" = teleios) (NE 1103a1525). So too in cities, "the legislators make the citizens good by habituating them." And thus, "To sum up in a single account, a state of character (bexis) results from the repetition of similar activities" (NE 1103b21), where "similar" does not mean mere mechanical repetition of a statistically inductive sort, but, rather, in the tychistic, pluralistic universe of human conduct, productively arises by qualitative continuity and growth of Logical Interpretants. Aristotle caps this discussion in Book Two, chapter one, with his characteristically perspicacious clarity: "It is not unimportant, then, to acquire one sort of habit or another, right from our youth. On the contrary, it is very important, indeed all-important" (NE 1103b24-25).

Once again, this is arguably, in nuce, the classical provenance for Peirce's generalized sense of personality as a developmental teleology. Depending on the "all-importance" of habituation "right from our youth," the whole ensemble of concepts returns us to Peirce's premises expressed in Some Consequences of Four Incapacities (1868) concerning the "Man-sign," as well as his up-dated version of the Man-Sign as developmental personality in The Law of Mind (1892). Moreover, from the beginning of his career-blossoming three-dimensional semeiotics, Peirce characterized pleasures and pains as "secondary phenomena"-pleasures and pains categorically considered (as Seconds), convergent with James' empirical doctrine of organic "sounding-boards" of neurological systems, where emotions arise in "hairtrigger" concomitant sensations of the external world and "hair-trigger" emotional reactions and actions.

Likewise, the function of Aristotle's mean (mesotes, intermediate) qua active perceptual judgment advanced an arguably comparable version of Logical Interpretant of the Peircean conduct of life-that is, "of the reason-able good not merely of the pleasant." But to re-emphasize a previous point, "our account can only be stated in outline," since it "up to us" as individual agents to realize the human form of Happiness. "Up to us," because "questions about actions and expediency, like questions about health, have no fixed answer" (NE 1104a1-4). Therefore, in this pragmatistic domain, "The account of particular cases is even more inexact. For these fall under no craft or profession; the agents themselves must consider in each case what the opportune action is, as doctors and navigators do" (NE 1104a5-10).

But again, habituation by the existentially variable mean (mesotes, intermediate) of perceptual judgment in the proceptive form of the Qualitative Interpretant increasingly strengthens our realization that "pleasures and pains" tend naturally to ruin the developmental teleology of character by excess or deficiency-"just as too much or too little eating and drinking ruin health." Therefore, "virtue of character 
is about pleasures and pains; and for this reason too, virtue is about pleasures and pains" (NE 1104b14-18). "For pleasure causes us to do base actions, and pain causes us to abstain from fine ones." Further, "pleasure grows up with all of us from infancy onward, and that is why it is hard to rub out this feeling that is dyed into our lives." (NE 1105a3-4).

The bottom line here is that, for Aristotle and Peirce, "it is hard to be virtuous." It is hard to be "reasonable" - that is to say, to be sensitively and resiliently reasonable, both in the cognitive and practical spheres of our lives, except for the Mansign's semeioically discoverable affinity (connaturality) with nature's karmic features which offer ameliorative prospects of qualitative accomplishments in the Kósmos Noetós. The symbolical Thirdness dimension of life allows for what in business parlance is called "a reasonable rate of return." (But the ontological semeiotics of the Kósmos Noetós is hard to learn).

At any rate, this pragmatistic problematic centers on the powers of the reactivating potency of the qualitatively inductive mean (mesotes) to transmute the "secondary phenomena" of "feelings and actions" and their attendant "pleasures and pains" into ameliorative accomplishments of the rational soul. The contrary implicates the rational mind's loss of freedom in futuro. Aristotle's theme of "intermediate" moral reckoning resurfaced as the heuristic thread in the ensuing books and chapters of the Nicomachean Ethics. It was naturally the theme of Book Six's articulation of "Prudence" (phronêsis) and "Wisdom" (sophia), and of Book Seven's account of Continence (enkratês) and Incontinence (akratês, the latter in excesses and deficiencies of "impetuosity" and "softness," respectively) of a rationally endowed soul which, unlike the immoderate vices and especially the immoderate vice of intemperance, involves the redeeming power of virtuous confrontation and decision).

Books Eight and Nine of the Nicomachean Ethics are similarly latticed in terms of the virtuous varieties and degrees of Friendship (philia). Book Ten reprises the theme of pleasures and pains as the supervenient attendants of the immoderate activities of the vicious, and the emotional instability of incontinent, kinds of personalities. Book Ten then famously circles back to the generic theme of the final entelechy of Happiness (eidaimonia) as "completing" a good life by way of featuring the positive, god-like form of human fulfillment achieved in devotion to the fulfillments of reflective participation (cf. Peirce's "Musement" in the Kósmos Noetós). Such themes of the active functions and fulfillments of Aristotle's mesotes qua Logical Interpretant (or its absence in the fixating universality of Crude Emotional Interpretant) can be further pursued with precision and in detail in the later books of the Nicomachean Ethics.

\section{Concluding thoughts}

But here, in conclusion, let me return to my general recommendation that Peirce's concept of Logical Interpretant can be appreciated as a reciprocally interpreting generalization in respect of Aristotle's principle of mesotes. I have noted that Peirce even pursued a speculative neo-Aristotelian variation of "Reasoning and the Logic of Things" in symbolically religious terms of evolutionary Agapism in his essay Evolutionary Love (1893). Indeed, this incomparably astute metaphysical 
essay went on to articulate three forms of cosmical and human Thirdness-first, the degenerate "greed gospel" form of Darwinian natural selection; second, the degenerate catastrophic-environmental and internally logical forms of predetermined anancasm; third, the agapistic "reasonsable rate of return" form of the noetic Universe's potential trajectories of breakthrough and growth. Further study of his tri-valent categorical determinations will reveal these "vague" metaphysical concepts have their abundant correlates within the range of subject matters articulated in Aristotle's philosophical treatises. ${ }^{39}$

Among the wide array of theories and practices in the history of civilization, the Nicomachean Ethics is preeminently "methodical" in the widest philosophic sense. It is par excellence anthropologically "Man-signed" in its articulation of the essential philosophic platform of the normative requirements of human happiness (in the interconnected but not collapsible spheres of personal and political conduct). It is a hologram of the wider ranges of an ontologically articulated worldview. And my argument has been that Aristotle's is arguably the classical hologram of Peirce's architectonic, ultimately semeiotic, interests. In key respects, Peirce's semeiotic worldview is a speculative generalization of Aristotle's, to the extent that, with exercise of metaphysical imagination, it naturally comes to mind to correlate Aristotle's moral universe of pragmatistic teleology with Peirce's universe of "generative" agapismwhile, in other respects, accounting for the degenerate forms of nature and mind (such as the "reactive" forms of the Crude/Emotional Interpretant in the Fixation of Belief) in the same fundamental terms.

To be sure, in historical perspective, Peirce's worldview was post-Kantian; it hewed close to the "progressive metaphysical empiricism" he found in Schelling's "Positive Philosophy." ${ }^{40}$ Accordingly, the open-endedness of his epistemological fallibilism departed from Aristotle's doctrine of the demonstrative use of reason (theoria), and all its variants in the history of mathematical, philosophic, and scientific intelligence; but, mutatis mutandis, he hewed close to the essential gist of Aristotle's sense of moral praxis in a Kósmos Noetós. Peirce's early-phase epistemology of the "Man-sign"-with its positive and negative entailments for "proud man's" glassy

39 With respect to the semeiotic distinction between Crude/Emotional and Logical Interpretants, Peirce's early epistemology outline of three degenerate forms of fixing belief in The Fixation of Belief (1877) adumbrated the types of cosmological evolution Peirce framed in Evolutionary Love (1893). Arguably, fixation by subjective Tenacity corresponds to the degenerate Darwinian form of natural selection by survival of the fittest; the degenerate fixation of belief by Authoritarianism to the type of externally compelling anancasm; degenerate fixation of belief by Apriorism corresponds to that of internal (logicist) anancasm. A further parsing of the latter might proceed along the lines of noting that the fixation of belief by Apriorism tends to produce "schools of philosophy," not to mention to become "congregational," as in Richard Niebuhr's account of "the scandal of Protestant denominations" and its update in the turf-defending "congregations" of contemporary philosophical scholasticism. Such "guild"-forms of "oneidea'd" professionalism (Analytic, Continental, Pragmatist, etc.) seem analogous to the institutionalized varieties of identities of "habit"-wearing religiosi that formed in medieval monastic communities (the Franciscans, Dominicans, Capuchins, etc., extending to the Jesuits and others in the Renaissance).

40 See Dilworth, 2015a, 2015b. 
essence-blossomed into a far-ranging cosmological and semeiotic categoriology culminating in his so-to-speak kalagathological worldview of evolutionary Agapism. Taking into due account the historical differences, Aristotle and Peirce shared such a bottom line trajectory of affirming the potentialities of qualitative progressions of "concrete reasonableness" in all forms of excellent semeiotic perfusion of the Beautiful, the Good, and the True-in a Kósmos Noetós having an activating "character" ( hexis) through its "mediating" power of the Logical Interpretant.

In achieving such generality of a noetic, objectively idealistic, worldview, Peirce can arguably be acclaimed the modern Aristotle. Of the three modalities of evolution Peirce described in Evolutionary Love (1893), his categorical agapism paralleled the energetic-entelic function of Aristotle's mesotes. Which is to say that in Peirce's expanded semeiosis of the universe's potentialities for synechistic amelioration, the Logical Interpretant performs a catalytic role in evolution's ascendant learning process. Aristotle's classical mesotes merged the formal, efficient, and final causes of contingent experience into consummate accomplishments of an ethical worldview. Peirce re-framed such a connatural power of energetic reasonableness as a cosmichuman potency for achieving good semeiotic outcomes in the perfuse sign-language of the Universe.

\section{References}

ARISTOTLE. Nicomachean Ethics. Translated by Terence Irwin. $2^{\text {nd }}$ Ed. Indianapolis: Hackett Publishing Co., 1999. [Irwin's translation is quoted as NE followed by number].

Nicomachean Ethics. Translated by Sarah Brodie and Christopher Rowe. Oxford and New York: Oxford University Press, 2002.

Aristotle's Nicomachean Ethics. Translated by Robert C. Bartlett and Susan D. Collins. Chicago: Chicago University Press, 2011.

The basic works of Aristotle. Edited by Richard McKeon. New York: Random House, 1941.

DILWORTH, David. Philosophy in world perspective: a comparative hermeneutic of the major theories. New Haven: Yale University Press, 1989.

Peirce's Schelling-fashioned critique of Hegel. Cognitio: revista de filosofia, São Paulo, v. 16, n. 1, p. 57-86, Jan./Jun. 2015 a.

Peirce's last philosophic will and testament: Uberty in the logic of instinctive reasoning. Cognitio: revista de filosofia, São Paulo, v. 16, n. 2, p. 233-258, Jul./Dec. 2015 b.

EVERETT, Daniel E. Peirce: the American Aristotle. In: Aeon.co. Available on: <https://aeon.co/essays/charles-sanders-peirce-was-americas-greatest-thinker>, 2019. Accessed on: 20 AGO 2019. 
GUARDIANO, Nicholas. Transcendental Encounters with a Universe Perfused with Signs, 2019. (pre-published).

HUME, David. Enquiry concerning the Principles of Morals. Oxford: Clarendon Press, 1998.

IBRI, Ivo A. The twilight of reality and the melancholic irony of brilliant, unlasting success: reflecting on emotional and logical interpretants. In: The American Philosophy Forum. Atlanta: Emory University, 2017 a.

. Kósmos Noetós: the metaphysical architecture of Charles S. Peirce. Translated by Henry Mallet. Cham: Springer, 2017b.

. The semiotic resilient mind: conflictual and agapic relationship between logical and emotional interpretants. In: The SSA conference. Kentucky. 2018a.

. Habits and kinds of induction: some forgotten remaining cases. In: Paper for a Rome, Italy conference, 2018b.

Habit formation and self-organization: a Peircean approach. In: PEREIRA Junior, Alfredo; PICKERING, William A.; GUDWIN, Ricardo R. (Eds.). Systems, selforganization and Information: an interdisciplinary perspective. New York and London: Rutledge, 2019, p. 177-193.

JAMES, William. Principles of psychology. New York: Henry Holt and Company, 1890. $2 \mathrm{v}$.

KANT, Immanuel. Critique of the power of judgment. Translated by Paul Guyer and Eric Matthews. Cambridge: Cambridge University Press, 2000.

KIM, Alan. An antique echo: Plato and the Nazis. In: ROCHE, Helen; and DEMETRIOU, Kyriakos N. (Eds.). Brill's Companion to the Classics: Fascist Italy and Nazi Germany. Leiden: Brill, 2017, p. 205-237.

KRUSE, Felicia. Nature and semiosis. Transactions of the Charles S. Peirce Society. v. 26, n. 2, p. 211-224, Spring 1990.

Peirce's sign and the process of interpretation. In: HART, Robert E.; and ANDERSON, Douglas R. (Eds.). Philosophy in experience: American philosophy in transition. New York: Fordham University Press, 1997, p. 128-152.

PEIRCE, Charles S. Collected Papers of Charles Sanders Peirce. Edited by HARTSHORNE, C. WEISS, P. \& BURKS, A. W. Cambridge: Harvard University Press, 1931-1958. 8 v. [Cited as CP followed by a number refers to volume and paragraph].

The Charles S. Peirce Papers. 32 microfilm reels of the manuscripts kept in the Houghton Library. Photographic Service. Cambridge, MA: Harvard University Library, 1966. [Cited as MS followed by a number refers to manuscript, page, and year]. 
Semiotic and Significs: the correspondence between Charles S. Peirce and Victoria Lady Welby. Edited by HARDWICK, C. S.; and COOK, J. Bloomington: Indiana University Press, 1977. [Cited as SS followed by a page].

. The Essential Peirce: selected philosophical writings. Edited by HOUSER, N. et al. Bloomington: Indiana University Press, 1992-1998. 2 v. [Cited as EP followed by a number refers to volume and page].

Writings of Charles Sanders Peirce: a chronological edition. Edited by the Peirce Edition Project. Bloomington, Indiana: Indiana University Press, 1982-2010. $8 \mathrm{v}$. [Cited as W followed by a number refers to volume and page].

Reasoning and the logic of things: The Cambridge Conference Lectures of 1898. Edited by Kenneth Laine Ketner, Cambridge, Mass.: Harvard University Press, 1992. [Cited as RLT followed by a number page].

ROBIN, Richard. Annotated catalogue of the papers of Charles S. Peirce. Amherst: University of Massachusetts Press, 1967.

SCHOPENHAUER, Arthur. The world as will and representation. Translated by E. F. J. Payne. New York: Dover, 1960. 2 v.

VASSANYI, Miklos. Anima Mundi: the rise of the world soul theory in modern German philosophy. Dordrecht, Heidelberg, and New York: Springer, 2011. 